University of Arkansas, Fayetteville

ScholarWorks@UARK

Education Reform Faculty and Graduate

Students Publications

$12-29-2016$

\title{
Helping Hand or a Hurdle Too High? An Evaluation Of Developmental Coursework at Arkansas's Flagship University
}

\author{
Evan Rhinesmith \\ University of Arkansas, Fayetteville, etrhines@email.uark.edu
}

Follow this and additional works at: https://scholarworks.uark.edu/edrepub

Part of the Educational Assessment, Evaluation, and Research Commons, Educational Leadership Commons, and the Other Educational Administration and Supervision Commons

\section{Citation}

Rhinesmith, E. (2016). Helping Hand or a Hurdle Too High? An Evaluation Of Developmental Coursework at Arkansas's Flagship University. Education Reform Faculty and Graduate Students Publications. Retrieved from https://scholarworks.uark.edu/edrepub/19

This Article is brought to you for free and open access by the Education Reform at ScholarWorks@UARK. It has been accepted for inclusion in Education Reform Faculty and Graduate Students Publications by an authorized administrator of ScholarWorks@UARK. For more information, please contact scholar@uark.edu. 


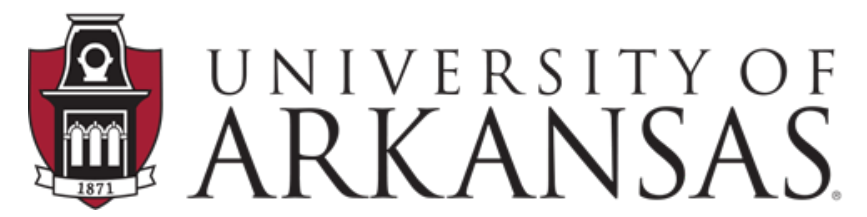

College of Education \& Health Professions Education Reform

\title{
WORKING PAPER SERIES
}

\section{Helping Hand or a Hurdle Too High? An evaluation of developmental coursework at Arkansas's flagship university}

\author{
Evan Rhinesmith
}

December 29, 2016

\section{EDRE Working Paper 2017-01}

The University of Arkansas, Department of Education Reform (EDRE) working paper series is intended to widely disseminate and make easily accessible the results of EDRE faculty and students' latest findings. The Working Papers in this series have not undergone peer review or been edited by the University of Arkansas. The working papers are widely available, to encourage discussion and input from the research community before publication in a formal, peer reviewed journal. Unless otherwise indicated, working papers can be cited without permission of the author so long as the source is clearly referred to as an EDRE working paper. 


\section{Helping Hand or a Hurdle Too High? An evaluation of developmental coursework at Arkansas's flagship university ${ }^{1}$}

Evan Rhinesmith (etrhines@email.uark.edu)

Department of Education Reform

University of Arkansas

201 Graduate Education Building

Fayetteville, AR 72701

P: (479) 575-3172; F: (479) 575-3196

Evan Rhinesmith is a doctoral candidate and Doctoral Academy Fellow in the Department of Education Reform at the University of Arkansas.

1 Thank you to the panel members at the $41^{\text {st }}$ Annual Meeting of the Association for Education Finance and Policy for comments on earlier drafts. All remaining flaws and errors are the responsibility of the author. Corresponding author is Evan Rhinesmith, etrhines@emailuark.edu. 


\begin{abstract}
High school graduation serves as an important gateway to increased professional opportunities. Not only does a high school graduate improve the national economy, a high school diploma is the key to opening the door to college. However, obtaining a high school degree does not necessarily ensure college readiness. In fact, many high school graduates are not prepared for college coursework, but still apply to and attend college in our college for all system. The class of 2013 saw only 38 percent of students test at a level considered prepared for college on the reading portion of the NAEP, but the problem is 66 percent of these students went on to enroll in college (Petrilli, 2016). In order to rectify this situation of unprepared students entering post-secondary education, colleges have implemented developmental coursework policies to prepare students for college-level coursework. Here, we add to the literature by examining the impacts of developmental coursework on students at Arkansas's flagship public institution. We use a regression discontinuity design to examine multiple bandwidths of student-level observations for first-time enrollees from 2003-2014. The full sample includes 40,395 first-time enrollees for the time period of interest, 92 percent reported scores for each of the three ACT sections that determine recommendation for remediation. Using marginal effects to predict outcomes, we find that students recommended to developmental math courses are less likely to persist in college and less likely to graduate in 4 years after enrollment. We find that students recommended for developmental English coursework were more likely to persist into the second semester and year of college but were less likely to graduate in 4 years. We conclude that developmental coursework at the University of Arkansas, while having mixed impacts on students, could be due to the quality of student choosing to attend the state's flagship institution and the state's policies tied to opting-in and placing-out of developmental courses.
\end{abstract}

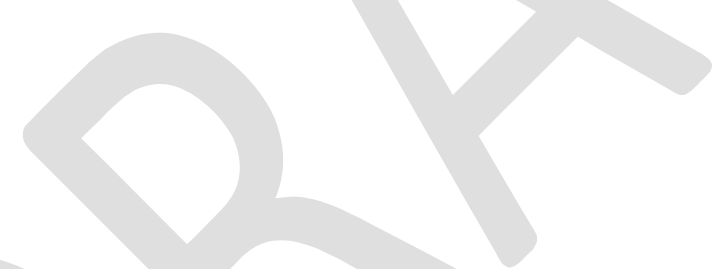

Keywords: Developmental coursework, remediation, postsecondary education, higher education policy, persistence, graduation 


\section{Introduction}

High school graduation serves as an important gateway to increased professional opportunities.

Completing high school is an important gateway to economic success. As Henry Levin and Cecilia Rouse voiced in a 2012 New York Times op-ed, "A typical high school graduate will obtain higher employment and earnings_-an astonishing 50 percent to 100 percent increase in lifetime income". High school graduates are also less likely to be incarcerated and less reliant on public assistance programs such as welfare and healthcare (U.S. Bureau of Labor Statistics, 2008; Baum and Ma, 2013; Harlow, 2003).

Not only does a high school graduate improve the national economy, a high school diploma is the key to opening the door to college. High school graduates are a benefit to society, but these benefits pale in comparison to the benefits of college degrees. According to a 2008 report from the Alliance for Excellence in Education, the lifetime earnings for individuals with a Bachelor's degree are more than double that of an individual who only holds a high school diploma.

However, obtaining a high school degree does not necessarily ensure college readiness. In fact, many high school graduates are not prepared for college coursework, but still apply to and attend college in our college for all system. The class of 2013 saw only 38 percent of students test at a level considered prepared for college on the reading portion of the NAEP, but the problem is 66 percent of these students went on to enroll in college (Petrilli, 2016). If we look at the class of 2009 (college class of 2013, six-year grad year 2015), 38 percent tested at the college preparedness level and 70 percent enrolled (Petrilli, 2016). The National Student Clearinghouse's most recent college completions report examined the high school class of 2009, finding a six-year completion rate of 53 percent, a decline of 2 percentage points for the class of 2008 (NSC, 2015). In order to rectify this situation of unprepared students entering post-secondary education, colleges have implemented remediation policies to prepare students for college-level coursework. 
During the 2007-08 school year, public institutions of higher education in the U.S. required approximately one-fourth of first-year college enrollees to complete remedial coursework (NCES, 2013). While the stated purpose of remedial coursework is to prepare seemingly unprepared students for college-level coursework, critics of remediation argue that benefits do not outweigh the costs. The crux of this argument is that remediation is a barrier to college-level coursework, lowering the chances of persistence and completion. Additionally, enrolling in remedial coursework may lower students' self-esteem, self-perceptions, and educational expectations, negatively affecting student outcomes (Deil-Amen \& Rosenbaum, 2002). Not only are the impacts on students an issue, but the financial ramifications of remediation are also a concern. An estimate from Breneman \& Haarlow (1998) suggested that public universities spend $\$ 1$ to $\$ 2$ billion annually on remediation. A more recent report on the cost of remediation at Florida community colleges (the third largest network of community colleges in the U.S.) found the cost to be $\$ 118.3$ million during the 2004-05 school year, 53 percent of which was paid by the state (Office of Program Policy, 2006).

Given these costs, it is no wonder policymakers have begun to question the benefit of remedial coursework. Remedial courses at the college level are designed to improve the outcomes for less prepared students. The problem with paying for college remediation, in the eyes of policymakers, is that we are effectively paying for colleges to teach students something they should have learned in high school. Because of this, states have begun to limit the availability of remedial education. In the 1990s, several states moved all of the available remedial coursework to community college campuses, while other states concerned with the use of tax dollars for colleges to teach high school courses proposed requiring public schools to pay for the remedial coursework of their graduates (Merisotis \& Phipps, 2000). One of the states that has been limiting the availability of remedial coursework at 4-year college campuses is Arkansas. 
The remainder of this paper is organized as follows. Section 2 reviews the relevant literature and explains methodological challenges with evaluating remedial education at the University of Arkansas. Section 3 describes the data and remediation policy at the University of Arkansas. Section 4 describes the methods used including the use of regression discontinuity and dealing with policy non-compliance. Section 5 discusses the analysis and results and section 6 presents the conclusion.

\section{Relevant Literature}

Developmental coursework policies have been in place at 2-year and 4-year postsecondary

institutions for decades, with the goal of helping students who may lack the academic background to initially succeed at the college level. Supporters of developmental coursework policies argue that these recovery courses help inadequately prepared students better succeed when they eventually enroll in credit-bearing courses. Conversely, developmental coursework opponents claim developmental coursework is costly to students who must enroll in non-credit bearing, non-GPA aiding courses and to the universities offering the courses. Due to the contentious nature of developmental coursework policies and the sheer size of the student populations enrolling in postsecondary institutions — and therefore developmental courses ${ }^{2}$ — researchers have devoted a great deal of effort to evaluating these policies to examine the impact these policies have on students in the short and long-term outcomes for students' academics and attainment.

While the ideal research design would make use of randomized control trial, assigning some students to receive treatment and others to carry on with business as usual. However, the goal of these developmental course policies is to help students who lack more rigorous academic backgrounds prior to college and, therefore, do not lend themselves to randomized control trials.

\footnotetext{
${ }^{2}$ It is important to note that in this research, I use the term "developmental coursework" in place of "remediation", as it is the preferred terminology among educators in the state of Arkansas. Research in other states often uses the terms "remediation" and "developmental" interchangeably. Though these differ in some settings, where "remedial" is reserved for courses meant for students who have scored the lowest on placement exams and "developmental" is reserved for students scoring just below the cutoff for college-level coursework (e.g. Boatman \& Long, 2010).
} 
Instead, researchers must make use of quasi-experimental methodologies to attempt to measure the causal impact of these developmental coursework policies. In most cases, due to the unique cut score policies assigning students to developmental coursework, many researchers have been able to make use of regression discontinuity designs (RDD). It is important to note that the use of RDDs leave results that are only generalizable to students right around the cutoff point.

In one of the earliest studies of college developmental coursework to use more rigorous methods, Bettinger and Long (2006) assessed the college performance and graduation outcomes for approximately 28,000 students in public colleges and universities in Ohio from 1998-2002. Ohio standards allowed individual universities autonomy to determine the cutoff for developmental coursework, leading to variation in the proficiency thresholds used to assign first-time college students at different institutions. Because of this, the authors use an instrumental variable combining this variation in placement cutoffs and the importance of distance from home to school to estimate the causal impacts of college developmental coursework on student outcomes such as persistence. They found that students in Ohio were more likely to persist and graduate when compared to student with similar test scores and backgrounds who did not enroll in developmental coursework. Also, they found that community college student developmental coursework math were 15 percent more likely to transfer to a 4-year college than similar students. These results from Bettinger and Long (2006) suggest developmental courses are valuable to students, at least in Ohio.

Using longitudinal data from the National Educational Longitudinal Study (NELS:88), Attewell et al (2006) test whether developmental courses lead community college students to accumulate fewer credits or delay the time to degree. For the student included in NELS:88, 40 percent took at least one developmental course, with mathematics being the most commonly developmental subject and more common among students enrolling at 2 -year colleges. They did find that developmental coursework has no negative impact on students at community colleges, but did 
lower the average chances of graduation for students enrolling in developmental coursework at 4year institutions by 6-7\%. Additionally, students at 4-year institutions who enrolled in developmental courses in reading experienced significant negative impacts on graduation, while developmental writing had no impact and math effects were unclear. These results, while positive for student enrolling in community colleges, were harmful for student at 4-year institutions.

A 2009 study from Martorell and McFarlin looked at college developmental courses for firsttime college enrollees at two- or four-year colleges in Texas between 1991-92 and 1999-2000 using the Texas School Microdata Panel. This provided observations on over 450,000 students and allowed the researchers to look at long-term impacts of developmental coursework. Texas uses a single placement exam, the Texas Academic Skill Program (TASP), for students to demonstrate college readiness by surpassing a single cut score. This presented the opportunity for the researchers to use a regression discontinuity to analyze the impacts of college developmental courses on Texas students. Failing to show college readiness was fairly common occurrence for Texas students enrolling in both 2- and 4- year institutions, $40 \%$ and $21 \%$ respectively. Failing any section of the exam required students to enroll in developmental coursework for that subject at the college level. Martorell and McFarlin find that, overall, developmental coursework has little effect on educational and labor market outcomes, including: that developmental courses neither increases time to graduation nor improves chances of graduation for developmental students. It is a similar result for long-term labor outcomes, showing that developmental courses were neither harmful nor beneficial to students in Texas.

Similar to Martorell and McFarlin, Boatman and Long (2010) examined the impacts of developmental coursework at public postsecondary institutions in the state of Tennessee. However, Tennessee's policy uses a multi-tiered course recovery system, where the lowest scoring students enroll in "remedial courses", requiring multiple courses prior to enrolling in college-level courses, 
and those scoring slightly below the cutoff enroll in "developmental courses", requiring only one course prior to college-level courses. Boatman and Long use a regression discontinuity with multiple cutoffs to estimate the causal effects of the different levels of developmental courses on credits earned, persistence, degree completion, and grade earned in first college-level courses. Similar to other research, students closer to the cutoff and enrolling in the upper-tier courses were less likely to earn a degree in 6 years and earn fewer credits compared to their peers enrolling in college-level courses. Interestingly, students placing into the lower level math courses did marginally worse than their peers in higher-tier courses, while students in lower-level writing courses persisted and attained a degree at higher rates than students in higher-level non-credit bearing courses. These results for students just below the cutoff are similar to other research, though the results from lower-level courses suggest that more remediation in certain subjects may be beneficial to students.

Calcagno and Long (2008) used data from Florida community colleges along with a regression discontinuity design to estimate the causal effect of developmental courses on student outcomes. They also must address a similar problem to this paper, noncompliance with assignment to developmental coursework. The results are, again, inconclusive for developmental coursework. They have observations for nearly 100,000 students at 28 different Florida community college campuses. They do find that students who enroll in developmental math were more likely to persist into their second year of college and to earn more credits than their non-developmental counterparts. However, this positive result for credits earned for developmental students disappears when accounting for non-developmental coursework courses.

Much like previous research, Scott-Clayton and Rodriguez (2012) and Dadgar (2012) both made use of a regression discontinuity design to measure the impacts of developmental coursework at the community college level in a Large Urban Community College System and Virginia, respectively. Scott-Clayton and Rodriguez had a much larger sample, with over 100,000 observations 
compared to Dadgar's researcher, which limited the sample to just over 5,000 students who completed the Pre-Algebra section of the COMPASS test. Similar to Boatman and Long, Dadgar examined the impact of being assigned to the lowest tier of developmental math courses and found that the lowest ability students who would be in these courses and have to complete three rather than two developmental courses experienced a 9 to 15 percentage point reduction in the likelihood of earning a credential within 4 years of enrolling. While the impacts of developmental coursework in Virginia appear to be negative, Scott-Clayton and Rodriguez finings lean toward developmental course policies having no impact, similar to that of Martorell and McFarlin, where developmental coursework does little to actually develop students' skills to succeed in college.

As shown in the previous literature, studies of developmental coursework have resulted in mostly null to negative outcomes for the students. This is especially true for research making use regression discontinuity methodologies, where researchers have found little impact on persistence, earning credentials, or earning more non-developmental credits. The lone study finding positive impacts comes from Bettinger and Long (2006) in Ohio, where the researchers make use of an Instrumental Variable and variation in course placement policies across institutions and find that students completing developmental courses are more likely to persist, transfer to a higher-level college and earn a bachelor's degree than students with similar placement scores and backgrounds. It is possible the lack of a centralized developmental coursework placement policy in Ohio has led to variation in the quality of developmental coursework across institutions in Ohio. In the case of Arkansas, there is a statewide minimum placement score for first-time enrollees, allowing this paper to use regression discontinuity methodologies. The subsequent section describes the data used to examine the impact of developmental coursework in Arkansas. 
Table: A review of experimental and/ or quasi-experimental published research on postsecondary developmental coursework.

\begin{tabular}{|c|c|c|c|c|c|}
\hline Study & Program/Location & Method & Sample & Outcome Measure(s) & Results \\
\hline $\begin{array}{l}\text { Attewell et al } \\
(2006)\end{array}$ & NELS:88, USA & $\begin{array}{l}\text { Quasi- } \\
\text { experimental }\end{array}$ & $\begin{array}{l}6,879 \text { students } \\
\text { completing surveys }\end{array}$ & $\begin{array}{l}\text { Earned a degree, time to degree, } \\
\text { persistence, earning } 10+\text { credits }\end{array}$ & $\begin{array}{l}\text { Null/Negative } \\
\text { No impact on community college } \\
\text { students, decreased chances of } \\
\text { graduation for students at 4-year } \\
\text { institutions }\end{array}$ \\
\hline $\begin{array}{l}\text { Bettinger \& Long } \\
(2006)\end{array}$ & $\begin{array}{l}\text { Developmental } \\
\text { courseworkial } \\
\text { coursework at Ohio } \\
\text { colleges and } \\
\text { universities }\end{array}$ & $\begin{array}{l}\text { Instrumental } \\
\text { Variable }\end{array}$ & $\begin{array}{l}28,376 \text { traditional-age } \\
\text { freshmen } 1998-2002\end{array}$ & $\begin{array}{l}\text { Persistence, transfer behavior, } \\
\text { degree completion for students in } \\
\text { and out of developmental } \\
\text { coursework }\end{array}$ & $\begin{array}{l}\text { Positive } \\
\text { Developmental courseworkiated } \\
\text { students more likely to persist, more } \\
\text { likely to transfer to a higher- } \\
\text { level/more selective college, } \\
\text { complete a 4-year degree }\end{array}$ \\
\hline $\begin{array}{l}\text { Calcagno \& Long } \\
\text { (2008) }\end{array}$ & $\begin{array}{l}\text { Developmental } \\
\text { coursework in Florida } \\
\text { community colleges }\end{array}$ & $\begin{array}{l}\text { Regression } \\
\text { Discontinuity }\end{array}$ & $\begin{array}{l}98,370 \text { students at } 28 \\
\text { FL community } \\
\text { colleges }\end{array}$ & $\begin{array}{l}\text { Passed first college-level course, } \\
\text { persist to } 2^{\text {nd }} \text { year, earn a } \\
\text { certificate, earn an Associate } \\
\text { Degree, transfer to 4-year } \\
\text { institution, credits earned, non- } \\
\text { developmental courseworkial } \\
\text { credits earned }\end{array}$ & $\begin{array}{l}\text { Null } \\
\text { Math students slightly more likely to } \\
\text { persist into second year, no effect on } \\
\text { non-developmental course credits, } \\
\text { reading students slightly less likely to } \\
\text { succeed in first college-level course }\end{array}$ \\
\hline $\begin{array}{l}\text { Martorell \& } \\
\text { McFarlin (2009) }\end{array}$ & $\begin{array}{l}\text { Texas Academic Skill } \\
\text { Program, first-time } \\
\text { enrollees in Texas 2- } \\
\text { year and 4-year } \\
\text { institutions }\end{array}$ & $\begin{array}{l}\text { Regression } \\
\text { Discontinuity }\end{array}$ & $\begin{array}{l}453,380 \text { freshmen } \\
\text { between } 1991-92 \text { and } \\
1999-00\end{array}$ & $\begin{array}{l}\text { Academic: credits attempted in } \\
\text { first year; total credits attempted; } \\
\text { transferring; persist into beyond } \\
\text { year } 1,2 \text {, and/or } 3 \text {; graduate in } 4 \text {, } \\
5 \text {, or } 6 \text { years } \\
\text { Earnings } 5,6 \text {, and } 7 \text { years } \\
\text { enrolling in college }\end{array}$ & $\begin{array}{l}\text { Null } \\
\text { Developmental coursework neither } \\
\text { increased nor improved time to } \\
\text { graduation or chances of graduating; } \\
\text { neither harmful nor beneficial to } \\
\text { labor market outcomes }\end{array}$ \\
\hline $\begin{array}{l}\text { Boatman \& Long } \\
(2010)\end{array}$ & $\begin{array}{l}\text { Tennessee; 2-year and } \\
\text { 4-year institutions }\end{array}$ & $\begin{array}{l}\text { Regression } \\
\text { Discontinuity }\end{array}$ & $\begin{array}{l}3,022 \text { students; } 704 \text { in } \\
\text { math \& } 2,318 \text { in } \\
\text { reading/writing }\end{array}$ & $\begin{array}{l}\text { Persistence, degree completion, } \\
\text { total/college-level credits earned, } \\
\text { and college GPA }\end{array}$ & $\begin{array}{l}\text { Mixed } \\
\text { Students in developmental math } \\
\text { accumulate fewer math credits and } \\
\text { no observable differences in } \\
\text { persistence } \\
\text { Students in lowest level } \\
\text { reading/writing courses persisted } \\
\text { more, attained degrees at higher } \\
\text { rates, and received higher grades in }\end{array}$ \\
\hline
\end{tabular}




\begin{tabular}{|c|c|c|c|c|c|}
\hline & & & & & first college-level writing course \\
\hline Dadgar (2012) & $\begin{array}{l}\text { Virginia; community } \\
\text { college cohort of } 2004\end{array}$ & $\begin{array}{l}\text { Regression } \\
\text { Discontinuity }\end{array}$ & $\begin{array}{l}\text { 5,440 students } \\
\text { completing } \\
\text { COMPASS Pre- } \\
\text { Algebra test }\end{array}$ & $\begin{array}{l}\text { Passing gatekeeper math course } \\
\text { and receiving a credential in } 4 \\
\text { years after enrollment }\end{array}$ & $\begin{array}{l}\text { Null/Negative } \\
\text { Assignment to third-tier (lowest) } \\
\text { developmental math courses reduces } \\
\text { likelihood of earning community } \\
\text { college credentials by } 9 \text { to } 15 \\
\text { percentage points } \\
\text { No impact on passing gatekeeper } \\
\text { course }\end{array}$ \\
\hline $\begin{array}{l}\text { Scott-Clayton \& } \\
\text { Rodriguez (2012) }\end{array}$ & $\begin{array}{l}\text { Large Urban } \\
\text { Community College } \\
\text { System }\end{array}$ & $\begin{array}{l}\text { Regression } \\
\text { Discontinuity }\end{array}$ & $\begin{array}{l}100,250 \text { students in a } \\
\text { Large Urban } \\
\text { Community college } \\
\text { System. }\end{array}$ & $\begin{array}{l}\text { Credits earned, degree } \\
\text { completion, decision to enroll, } \\
\text { grades in subsequent college } \\
\text { courses, post-developmental } \\
\text { coursework proficiency test } \\
\text { achievement }\end{array}$ & $\begin{array}{l}\text { Null/Negative } \\
\begin{array}{l}\text { No impact on enrollment, degree } \\
\text { completion, persistence, or semester } \\
\text { enrolled }\end{array} \\
\text { Assignment to developmental math } \\
\text { decreased likelihood of passing } \\
\text { college-level math; disappears in } \\
\text { reading \& writing; reading had } \\
\text { systematically negative impacts }\end{array}$ \\
\hline $\begin{array}{l}\text { Wolfle \& Williams } \\
\text { (2014) }\end{array}$ & $\begin{array}{l}\text { Virginia; community } \\
\text { college cohort of } 2006\end{array}$ & $\begin{array}{l}\text { Quasi- } \\
\text { experimental }\end{array}$ & 17,335 students & $\begin{array}{l}\text { Fall-to-fall persistence and success } \\
\text { in first college-level math course }\end{array}$ & $\begin{array}{l}\text { Mixed } \\
\text { Persistence for students in } \\
\text { developmental courses varied by age, } \\
\text { gender, and race } \\
\text { Students in developmental math } \\
\text { have } 12.4 \% \text { lower success rates in } \\
\text { first college-level course }\end{array}$ \\
\hline
\end{tabular}




\section{Postsecondary Remediation Policy at the University of Arkansas and the Dataset}

Unfortunately, Arkansas is below the national average for the number of residents holding two- or four-year college degrees (U.S. Census Bureau, 2010). This has been an area of concern in the Natural State. Former Arkansas Governor Mike Beebe made it a goal for Arkansas to double the number of college graduates by 2025. The Arkansas State Legislature, also recognizing the importance of increasing the number of Arkansans with a college degree, passed Act 1203 in 2011 to increase the state's college graduation rate. Also, Act 1203 looked to increase the rigor of coursework at the network of state universities. This act included an accountability measure for public universities in Arkansas in regards to funding.

Public universities in Arkansas receive only a portion of the funding from the state allocated to public schools. Act 1203 changed the funding formula for state universities and colleges to receive incentive funding based on measurable outcomes, beginning in 2014-15 until it comprises $25 \%$ of total state appropriations for college and universities in Arkansas. These outcome measures for incentive funding include student retention, course completion, and college graduation. According to the Arkansas State Board of Higher Education, universities in Arkansas must produce college graduates at a rate of nearly $5 \%$ higher than the state's current college graduation rate if the state is to double the number of college graduates.

With the requirement of increasing college graduation rates by $5 \%$ annually, there is a premium on Arkansas's universities to better retain new college enrollees and ensure they are adequately prepared for the rigors of college coursework. However, many recent high school grads are not academically prepared for success in college-level courses (Greene \& Forster, 2003). This lack of preparation for many high school graduates has resulted in states mandating that public institutions determine if students be placed in remedial or developmental courses before enrolling in degree-seeking courses. 
Despite the fact there has been a slight decrease in college remediation rates over the past twenty years, the percentage of students who are required to take remedial courses at Arkansas's colleges and universities is still greater than the national average. In the 2014-15 school year, approximately 31 percent of first-time enrollees were remediated in mathematics, $26 \%$ of first-time enrollees were remediated in English, and approximately 20\% of first-time enrollees were remediated in reading (Arkansas Department of Higher Education, 2015). The purpose of this remedial coursework is to help these first-time enrollees lacking adequate preparation to better succeed in college-level coursework. Because of this, it is not surprising that most states, including Arkansas, have specific requirements regarding college remediation.

In 1991, the Arkansas State Legislature passed Act 1101 mandating that all public institutions of higher education test first-time college enrollees. These placement tests are designed to determine placement in either college-level or remedial-level courses in English, reading, and mathematics. Students not meeting the proficiency threshold in any of these subject areas are recommended to complete remedial courses, which do not count as credit toward graduation. As of 2002, the Board has mandated that students scoring below a 19 on the math, English, and/or reading sections on the ACT are recommended to enroll in remediation, but any institution in Arkansas may set a higher minimum threshold.

The University of Arkansas follows the threshold set by the Arkansas Board of Higher Education's recommendation for all first-time college enrollees applying for admittance. Students are placed in a college-level, credit-bearing course in reading, math, and/or English based on students' scores on specific tests. The typical placement tests are the ACT and SAT. The cutoff score for all three ACT subject tests at the University of Arkansas is a 19. Students choosing to take the SAT are recommended for remediation in English or reading if they score below 470 on the verbal section or below 460 on the quantitative section. 
To examine the impact of remediation at the University of Arkansas, this study uses a dataset provided by the University of Arkansas for incoming freshman for 2003-2014. The administration at the University maintains complete records for the incoming freshman classes. The data used in this study include information on high school GPA, high school location, and ACT superscore that include students' highest composite and section scores. The data also includes demographic characteristics, including gender, race/ethnicity, parents' education, expected family contribution, and Pell grant eligibility used as a proxy for socioeconomic status. This paper focuses on the students who have ACT scores reported. The full sample includes 40,395 first-time enrollees for the time period of interest, 92 percent reported scores for each of the three ACT sections that determine recommendation for remediation.

The variables of interest in this study are assignment to remediation based on ACT score and participation in remedial coursework for all three subjects. The dataset also tracks term-by-term enrollment up to six years for each cohort. The short-term outcomes available for analysis in this dataset include fall-to-spring persistence during the first year of enrollment and fall-to-fall persistence. The long-term educational outcomes include 6-year graduation rates (only for students entering in the fall of 2008 and earlier) and 4-year graduation (for students entering in the fall of 2010 and earlier). The data also includes cumulative GPA and credits earned. We omit the outcomes on credits earned for the time being.

Summary statistics and trends in enrollment and remediation for the University of Arkansas are provided below in Table 1 and trends in enrollment and remediation are provided in Table 2. Column 1 shows the characteristics of all students who enrolled between the fall 2003 and 2014 who had an ACT score for at least one section. The second column describes the students for whom we have an available subject score in which the University offers remedial courses which is our research sample. Column 3 details the sample of students who scored below the cutoff in any of the 
remediated subjects, representing an Intent-to-Treat sample. The last two columns describe students who enrolled in a remedial course for math and English respectively. Comparisons of the columns show that students recommended for remediation were more likely to be minority and more likely to be female for math and male for English. Also, students recommended for remediation were more likely to be eligible to receive a Pell Grant and have a lower baseline academic achievement as measured by high school GPA. 
Table 1: Descriptive Statistics - University of Arkansas First-Time College Enrollees (fall 2003 to 2014)

\begin{tabular}{|c|c|c|c|c|c|}
\hline & Full Sample & $\begin{array}{l}\text { Research } \\
\text { Sample }\end{array}$ & $\begin{array}{l}\text { Recommended } \\
\text { Remediation } \\
\text { (Any) }\end{array}$ & $\begin{array}{l}\text { Enrolled in } \\
\text { Remediation } \\
\text { (Math) }\end{array}$ & $\begin{array}{l}\text { Enrolled in } \\
\text { Remediation } \\
\text { (English) }\end{array}$ \\
\hline Observations & 40,395 & 37,295 & 3,776 & 2,688 & 1,479 \\
\hline \multicolumn{6}{|l|}{ Demographics } \\
\hline Female & $51.30 \%$ & $51.75 \%$ & $56.38 \%$ & $63.28 \%$ & $35.02 \%$ \\
\hline African American & $4.84 \%$ & $4.88 \%$ & $13.61 \%$ & $15.40 \%$ & $15.62 \%$ \\
\hline White & $82.21 \%$ & $83.31 \%$ & $71.48 \%$ & $66.03 \%$ & $51.32 \%$ \\
\hline Asian & $2.43 \%$ & $2.51 \%$ & $2.49 \%$ & $1.41 \%$ & $3.59 \%$ \\
\hline Hispanic & $4.72 \%$ & $4.53 \%$ & $6.30 \%$ & $4.80 \%$ & $7.17 \%$ \\
\hline All other Races & $5.80 \%$ & $4.78 \%$ & $6.12 \%$ & $12.35 \%$ & $22.31 \%$ \\
\hline Pell Grant Eligible & $20.18 \%$ & $20.69 \%$ & $31.22 \%$ & $32.18 \%$ & $28.94 \%$ \\
\hline First Gen. College & $30.70 \%$ & $30.77 \%$ & $43.35 \%$ & $47.76 \%$ & $53.28 \%$ \\
\hline High School GPA & $\begin{array}{l}3.59 \\
(0.42)\end{array}$ & $\begin{array}{l}3.60 \\
(0.42)\end{array}$ & $\begin{array}{c}3.23 \\
(0.36) \\
\end{array}$ & $\begin{array}{l}3.20 \\
(0.37)\end{array}$ & $\begin{array}{l}3.21 \\
(0.40)\end{array}$ \\
\hline
\end{tabular}

\section{Expected Family \\ Contribution}

\begin{tabular}{llllll}
\hline Highest & $16.86 \%$ & $17.28 \%$ & $11.86 \%$ & $10.01 \%$ & $7.57 \%$ \\
\hline Higher & $16.88 \%$ & $17.26 \%$ & $12.24 \%$ & $10.83 \%$ & $8.72 \%$ \\
\hline Lower & $16.87 \%$ & $17.25 \%$ & $16.21 \%$ & $15.03 \%$ & $12.78 \%$ \\
\hline Lowest & $16.90 \%$ & $17.26 \%$ & $25.66 \%$ & $26.49 \%$ & $24.54 \%$ \\
\hline Unknown & $32.49 \%$ & $30.96 \%$ & $34.03 \%$ & $37.65 \%$ & $46.38 \%$ \\
\hline \multicolumn{1}{l}{ Test Scores } & & & & \\
\hline ACT Composite & 25.69 & 25.76 & 20.74 & 20.50 & 19.84 \\
& $(3.82)$ & $(3.84)$ & $(1.83)$ & $(1.87)$ & $(1.87)$ \\
\hline ACT Math & 24.81 & 24.81 & 18.46 & 17.20 & 20.48 \\
& $(4.27)$ & $(4.27)$ & $(2.56)$ & $(0.96)$ & $(3.04)$ \\
\hline ACT English & 25.97 & 25.97 & 20.16 & 21.44 & 16.73 \\
& $(4.77)$ & $(4.77)$ & $(3.40)$ & $(3.09)$ & $(1.64)$ \\
\hline
\end{tabular}

\section{Remediation}

\begin{tabular}{llllcc}
\hline Recmd. Math & $6.91 \%$ & $7.48 \%$ & $73.91 \%$ & $86.79 \%$ & $18.93 \%$ \\
\hline Remediated Math & $6.66 \%$ & $6.66 \%$ & $61.81 \%$ & -- & $30.63 \%$ \\
\hline Recmd. English & $3.38 \%$ & $3.66 \%$ & $36.18 \%$ & $10.19 \%$ & $69.98 \%$ \\
\hline Remediated English & $3.66 \%$ & $3.66 \%$ & $27.44 \%$ & $16.85 \%$ & --
\end{tabular}

Note: ACT section scores show averages above the cutoff score due to certain students being recommended for remediation in multiple subjects. 
Table 2: Descriptive Statistics for Selected Years- University of Arkansas First-Time College Enrollees

\begin{tabular}{|c|c|c|c|c|c|c|}
\hline \multicolumn{7}{|c|}{ Cohort Year } \\
\hline & 2003-04 & $2007-08$ & 2008-09 & 2011-12 & 2013-14 & 2014-15 \\
\hline Observations & 2,269 & 2,879 & 2,979 & 4,414 & 4,300 & 4,518 \\
\hline \multicolumn{7}{|l|}{ Demographics } \\
\hline Female & $51.83 \%$ & $49.50 \%$ & $49.95 \%$ & $51.16 \%$ & $52.72 \%$ & $54.60 \%$ \\
\hline African American & $4.76 \%$ & $4.62 \%$ & $5.54 \%$ & $5.23 \%$ & $4.63 \%$ & $4.87 \%$ \\
\hline White & $85.90 \%$ & $84.16 \%$ & $83.55 \%$ & $80.58 \%$ & $79.79 \%$ & $79.17 \%$ \\
\hline \multicolumn{7}{|l|}{ Hispanic } \\
\hline Asian & & & & 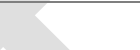 & & \\
\hline All Other Races & $7.49 \%$ & $9.93 \%$ & $9.70 \%$ & $12.94 \%$ & $14.44 \%$ & $14.70 \%$ \\
\hline First Gen. College & --- & $29.49 \%$ & $28.10 \%$ & $26.57 \%$ & $25.05 \%$ & $23.09 \%$ \\
\hline Pell Grant Eligible & $20.37 \%$ & $16.74 \%$ & $17.93 \%$ & $22.86 \%$ & $21.58 \%$ & $21.14 \%$ \\
\hline High School GPA & $\begin{array}{c}3.58 \\
(0.45)\end{array}$ & $\begin{array}{c}3.59 \\
(0.43)\end{array}$ & $\begin{array}{c}3.59 \\
(0.41)\end{array}$ & $\begin{array}{c}3.56 \\
(0.46)\end{array}$ & $\begin{array}{c}3.62 \\
(0.38)\end{array}$ & $\begin{array}{c}3.63 \\
(0.39)\end{array}$ \\
\hline
\end{tabular}

\section{Expected Family \\ Contribution}

\begin{tabular}{|c|c|c|c|c|c|c|}
\hline Highest & --- & $14.28 \%$ & $15.61 \%$ & $20.37 \%$ & $20.35 \%$ & $20.12 \%$ \\
\hline Higher & --- & $14.28 \%$ & $15.61 \%$ & $20.39 \%$ & $20.35 \%$ & $20.41 \%$ \\
\hline Lower & --- & $14.28 \%$ & $15.61 \%$ & 20.37 & $20.35 \%$ & $20.41 \%$ \\
\hline Lowest & -- & $14.31 \%$ & $15.64 \%$ & $20.41 \%$ & $20.37 \%$ & $20.41 \%$ \\
\hline Unknown & $100.00 \%$ & $42.83 \%$ & $37.53 \%$ & $18.46 \%$ & $18.58 \%$ & $19.46 \%$ \\
\hline \multicolumn{7}{|l|}{ Test Scores } \\
\hline ACT Composite & $\begin{array}{l}25.49 \\
(4.10)\end{array}$ & $\begin{array}{l}25.25 \\
(3.87)\end{array}$ & $\begin{array}{l}25.77 \\
(3.93)\end{array}$ & $\begin{array}{l}25.71 \\
(3.68)\end{array}$ & $\begin{array}{l}25.84 \\
(3.63)\end{array}$ & $\begin{array}{l}25.95 \\
(3.67)\end{array}$ \\
\hline ACT Math & $\begin{array}{l}24.12 \\
(4.74)\end{array}$ & $\begin{array}{l}24.89 \\
(4.34)\end{array}$ & $\begin{array}{l}24.97 \\
(4.42)\end{array}$ & $\begin{array}{l}24.80 \\
(4.08)\end{array}$ & $\begin{array}{l}25.13 \\
(3.95)\end{array}$ & $\begin{array}{l}25.07 \\
(3.98)\end{array}$ \\
\hline ACT English & $\begin{array}{l}25.89 \\
(4.80)\end{array}$ & $\begin{array}{l}26.10 \\
(4.73)\end{array}$ & $\begin{array}{l}25.93 \\
(4.87)\end{array}$ & $\begin{array}{l}25.96 \\
(4.66)\end{array}$ & $\begin{array}{l}25.97 \\
(4.70)\end{array}$ & $\begin{array}{l}26.18 \\
(4.74)\end{array}$ \\
\hline ACT Reading & $\begin{array}{l}26.29 \\
(5.10)\end{array}$ & $\begin{array}{l}26.48 \\
(4.93)\end{array}$ & $\begin{array}{l}26.44 \\
(4.98)\end{array}$ & $\begin{array}{l}26.33 \\
(4.82)\end{array}$ & $\begin{array}{l}26.45 \\
(4.81)\end{array}$ & $\begin{array}{l}26.66 \\
(4.74)\end{array}$ \\
\hline \multicolumn{7}{|l|}{ Remediation } \\
\hline Recmd. Math & $\begin{array}{c}299 \\
(13.18 \%)\end{array}$ & $\begin{array}{c}178 \\
(6.18 \%)\end{array}$ & $\begin{array}{c}194 \\
(6.51 \%)\end{array}$ & $\begin{array}{c}272 \\
(6.16 \%)\end{array}$ & $\begin{array}{c}220 \\
(5.12 \%)\end{array}$ & $\begin{array}{c}253 \\
(5.60 \%)\end{array}$ \\
\hline Remediated Math & 267 & 200 & 203 & 239 & 203 & 209 \\
\hline Recmd. English & $\begin{array}{c}108 \\
(4.76 \%)\end{array}$ & $\begin{array}{c}78 \\
(2.71 \%)\end{array}$ & $\begin{array}{c}114 \\
(3.83 \%)\end{array}$ & $\begin{array}{c}135 \\
(3.06 \%)\end{array}$ & $\begin{array}{c}116 \\
(2.70 \%)\end{array}$ & $\begin{array}{c}135 \\
(2.99 \%)\end{array}$ \\
\hline Remediated English & 103 & 104 & 131 & 112 & 126 & 117 \\
\hline
\end{tabular}


In Table 2, we can see that the percent of students qualifying for remediation has decreased since the first year of our dataset, which also corresponds to the year following the State Boards establishment of the cutoff score to qualify for remediation using the ACT. Also, it has continued to stay at this lower rate since 2011, when Governor Beebe declared his intention of doubling the number of college graduates in the state of Arkansas. This also corresponds to a decision in 1998 by the Arkansas State Legislature to decrease the amount of remedial coursework offered at 4-year institutions.

As we can see, not all students recommended for remediation in math enrolled in remedial coursework, while more students than were recommended for remediation enrolled in English. This has important implications for an analysis of the effectiveness of the remediation program at the University of Arkansas. This is not uncommon in regression discontinuity studies looking to determine the causal impact of an intervention (Angrist \& Lavy, 1999; Battistin \& Rettore, 2002; Van der Klaauw, 2002; Jacob \& Lefgren, 2004; Calcagno \& Long, 2008). This brings us to the first concern in our analysis of remediation: students who have ACT section scores that recommend their enrollment in a remedial course and do not enroll. In this case, students enrolling at the University can take an additional placement test after enrolling that supersedes their ACT score and allows them to enroll in credit-bearing courses. Also, for English courses, students can test out of remedial writing courses "by demonstrating college-level writing skills on a required essay administered during the first week of class (University of Arkansas Placement and Proficiency Tests, 2015." All students enrolling at the University are required to complete an online placement test in mathematics. Students earning a 70 percent or higher may enroll in a pre-college level algebra/college-level algebra combination course, or students earning an 80 percent or higher on the math placement test may enroll in college algebra without completing remedial math courses (University of Arkansas 
Placement and Proficiency Tests, 2015). This noncompliance is addressed in the empirical analysis, which is described below.

A greater concern is that of students retaking the placement test multiple times to avoid enrollment in remedial coursework. This would result in nonrandom sorting around the policy cutoff, which is a serious concern for regression discontinuity research (Imbens \& Lemieux, 2008; McCrary, 2008; Lee, 2008). Currently, we do not have access to this data to see if this is a situation that occurs and how often. This is a potential area to further the current research and improve the rigor of our analyses.

\section{Methods}

This section discusses the methods used to estimate the impact of remediation for students at the University of Arkansas. We present the methods of a regression discontinuity and the methodological challenges presented by an evaluation of this nature. This section begins with a description of the regression discontinuity design, followed by a discussion of the "fuzzy" regression discontinuity, and our methods to estimate the parameters of interest.

\section{Regression Discontinuity Strategy}

Ideally, we would be able to conduct a random assignment study, selecting a sample of students from the population and randomly assigning them to either receive the treatment or continue with business as usual as the comparison group. In this case, the comparison group is the counterfactual for estimating the effect of the treatment. Treatment is a binary indicator, where $\mathrm{T}=1$ for treatment and $\mathrm{T}=0$ for comparison and the difference in means of $\mathrm{Y}$ for each group is the causal effect of the intervention. This random assignment method is not fitting for studies of remediation interventions, as the rating variable determines the receipt of treatment. Regression discontinuity (RD) analysis is a fitting method for situations in which candidates are assigned to treatment based on their score relative to a numeric rating. In this case, a student's ACT score designating them as a candidate for remediation. 
The RD approach's use of the remedial placement rules and cutoffs allows for the estimate of the impact of remediation on long-term educational outcomes. In this case, we let A represent a student's ACT section score (the rating variable in our data), and $\overline{\mathrm{A}}$ represent the minimum score required to not be recommended for remediation. In this case, students who earn an ACT section score that is below $\overline{\mathrm{A}}$ are recommended for remedial coursework, and those scoring above are not recommended for remediation. Conducting a regression on observations immediately surrounding the rating score would yield the estimated treatment effect, which is the difference between the average outcome measures on either side of $\overline{\mathrm{A}}$.

Because of the nature of being assigned to remediation, there is an inherent selection problem for first-time college students who enroll in remediation compared to their peers who do not receive remediation. However, an $\mathrm{RD}$ approach assumes that, prior to treatment, the students immediately surrounding the rating variable will be similar. In the case of remediation at the University of Arkansas, this rating value is a 19 on a section of the ACT. Students scoring an 18 are recommended for remediation, while students scoring a 19 are free to enroll in credit-bearing courses. Thus, comparing these two groups of students is relevant due to the minute differences between students scoring an 18 and students scoring a 19, which are likely due to measurement error in the imperfect measure of academic preparation used to determine remediation. If this assumption is correct, the only systematic difference between those scoring an 18 and those scoring a 19 is enrollment in remedial coursework. We refer to this group of students as the narrow band sample. We also restrict our sample further to a wide band sample that includes students scoring between 17 and 20 on the ACT subject test of interest.

In Table 3 below we examine student-level covariates to show statistical equivalence in observable characteristics for all students seeking a degree at the University. This is meant to represent a test of random assignment around the rating variable. As we would expect, the means 
for observable student characteristics show statistically significant differences for the groups qualifying for remediation compared to those who do not when examining the full sample of students. These differences remain for some covariates when we shrink the sample to a smaller bin around the cutoff. These differences continue to disappear when we shrink our sample to the smallest bin of students scoring just below the cutoff to the students scoring right at the cutoff. However, there are differences in the proportion of female students (for math) and for minority students in all subjects. Also, students being recommended for remediation are also more likely to be first generation college students in both English and math. Non-remediated students are also likely to have achieved higher ACT Composite scores across all subjects.

While including these student-level covariates helps to minimize any imbalance around the discontinuity point (Lee, 2008), there could still be unobservable differences between the two groups. Additionally, there is a concern that students testing out of remediation or being recommended for remediation after placement is nonrandom and could be related to the educational outcomes of interest. The biggest concerns that potentially violate the assumptions of a sharp RD design that we are able to account for are crossovers and non-compliance. We describe how we account for these threats below. 
Table 3: Descriptive Statistics by Remedial Subject: Group Means and Differences

* Denotes significant difference at 1 percent level

\begin{tabular}{|c|c|c|c|c|c|c|c|c|c|}
\hline & \multicolumn{3}{|c|}{ Band Around Cutoff (all) } & \multicolumn{3}{|c|}{ Band Around Cutoff $(-2 /+2)$} & \multicolumn{3}{|c|}{ Band Around Cutoff $(-1 /+1)$} \\
\hline & All Below & All Above & Difference & $17-18$ & $19-20$ & Difference & 18 & 19 & Difference \\
\hline \multicolumn{10}{|l|}{$M A T H E M A T I C S$} \\
\hline Female & 0.659 & 0.502 & $0.157^{*}$ & 0.665 & 0.611 & $0.054^{*}$ & 0.658 & 0.612 & $0.046^{*}$ \\
\hline African American & 0.149 & 0.041 & 0.108 & 0.132 & 0.084 & $0.048^{*}$ & 0.129 & 0.094 & $0.035^{*}$ \\
\hline White & 0.721 & 0.830 & -0.109 & 0.737 & 0.798 & $-0.061 *$ & 0.747 & 0.790 & $-0.043^{*}$ \\
\hline Hispanic & 0.127 & 0.116 & 0.011 & 0.129 & 0.117 & 0.012 & 0.121 & 0.115 & 0.006 \\
\hline Asian & 0.015 & 0.025 & -0.010 & 0.017 & 0.017 & 0.000 & 0.017 & 0.015 & 0.002 \\
\hline Other Races & 0.063 & 0.058 & 0.005 & 0.060 & 0.047 & 0.013 & 0.058 & 0.049 & 0.009 \\
\hline Parent College Grad & 0.565 & 0.702 & $-0.137 *$ & 0.575 & 0.624 & $-0.049 *$ & 0.562 & 0.616 & $-0.054 *$ \\
\hline Pell Grant Eligible & 0.314 & 0.193 & $0.121 *$ & 0.295 & 0.266 & 0.029 & 0.297 & 0.276 & 0.021 \\
\hline HS GPA & 3.216 & 3.615 & $-0.399 *$ & 3.237 & 3.311 & $-0.074 *$ & 3.248 & 3.281 & -0.033 \\
\hline ACT Math & 17.210 & 25.422 & $-8.212^{*}$ & 17.603 & 19.533 & $-1.930 *$ & - & - & - \\
\hline ACT Composite & 20.694 & 26.060 & $-5.366^{*}$ & 20.928 & 21.960 & $-1.032 *$ & 21.149 & 21.695 & $-0.546^{*}$ \\
\hline Observations & 2,792 & 37,603 & & 2,220 & 3,642 & & 1,338 & 1,702 & \\
\hline \multicolumn{10}{|l|}{ ENGLISH } \\
\hline Female & 0.334 & 0.519 & $-0.185^{*}$ & 0.353 & 0.444 & $-0.091 *$ & 0.366 & 0.423 & -0.057 \\
\hline African American & 0.162 & 0.044 & $0.118^{*}$ & 0.133 & 0.091 & $0.042^{*}$ & 0.135 & 0.095 & 0.040 \\
\hline White & 0.650 & 0.828 & $-0.178^{*}$ & 0.695 & 0.760 & $-0.065^{*}$ & 0.693 & 0.764 & $-0.071 *$ \\
\hline Hispanic & 0.175 & 0.114 & $0.061 *$ & 0.164 & 0.146 & 0.018 & 0.163 & 0.137 & 0.026 \\
\hline Asian & 0.042 & 0.024 & 0.018 & 0.036 & 0.037 & -0.001 & 0.043 & 0.039 & 0.004 \\
\hline Other Races & 0.058 & 0.058 & 0.000 & 0.054 & 0.049 & 0.005 & 0.055 & 0.055 & 0.000 \\
\hline Parent College Grad & 0.542 & 0.698 & $-0.156^{*}$ & 0.549 & 0.602 & $-0.053 *$ & 0.533 & 0.598 & $-0.065^{*}$ \\
\hline Pell Grant Eligible & 0.327 & 0.197 & $0.130 *$ & 0.303 & 0.279 & 0.024 & 0.318 & 0.266 & 0.052 \\
\hline HS GPA & 3.211 & 3.601 & $-0.390 *$ & 3.228 & 3.275 & $-0.046^{*}$ & 3.244 & 3.256 & -0.012 \\
\hline ACT English & 16.680 & 26.327 & $-9.647^{*}$ & 17.630 & 19.626 & $-1.996^{*}$ & - & - & - \\
\hline ACT Composite & 20.312 & 25.876 & $-5.564 *$ & 20.655 & 21.295 & $-0.639 *$ & 20.773 & 21.040 & $-0.267^{*}$ \\
\hline Observations & 1,367 & 39,028 & & 894 & 3,015 & & 563 & 1,128 & \\
\hline
\end{tabular}


Fuг:y RD Design to deal with Noncompliance

In order to properly implement a sharp $\mathrm{RD}$, we must assume that all students recommended for remediation comply with their placement. However, our data show that there are differences between mandatory assignment to remediation and enrolling in remedial classes (receiving treatment). Because of this, the average probability of enrolling in an assigned remedial course could be less than one below the rating score and greater than zero above the rating score, signaling noncompliance with the policy. Similar to the noncompliance issues found in Calcagno and Long (2008) the University of Arkansas's remediation policy uses a single cut score to qualify for remediation, leading to two types of non-compliance: no-shows and crossovers (Calcagno \& Long, 2008). No-show students are students who qualify for treatment, but do not show up in the data as treatment students by testing out post-remedial recommendation as described above. Crossovers are students who are not recommended for remediation based on their ACT score in a particular section, but who receive the treatment either through the recommendation of a professor or scoring below the acceptable level on a placement test.

Figure 1 below shows the probability of enrollment in remedial courses for all three subjects by ACT score in corresponding subject. As shown in the graphs, there is at least an 80 percent chance of enrolling in remedial math when scoring below a 19 on the math section of the ACT. This means that there is around 20 percent of students qualifying for treatment who do not receive remediation. Also, we see slight jumps in the probability of enrolling in remediation for students who score above the cutoff, showing crossover students do exist in our dataset. There were few crossovers in reading and English remediation, but for reading, we do observe crossovers closer to the cutoff score. We do observe no-shows for both subjects, which could be due to students excelling in their initial writing assessments at the beginning of their first year of enrollment. With these observed crossovers and no-shows in all three subjects, it is more appropriate to classify our methods as a fuzzy regression-discontinuity (Campbell, 1969). This is a larger problem in our 
analysis of the full sample of students, as the narrow band focusing on the students scoring at and below the cutoff experience lower crossover.

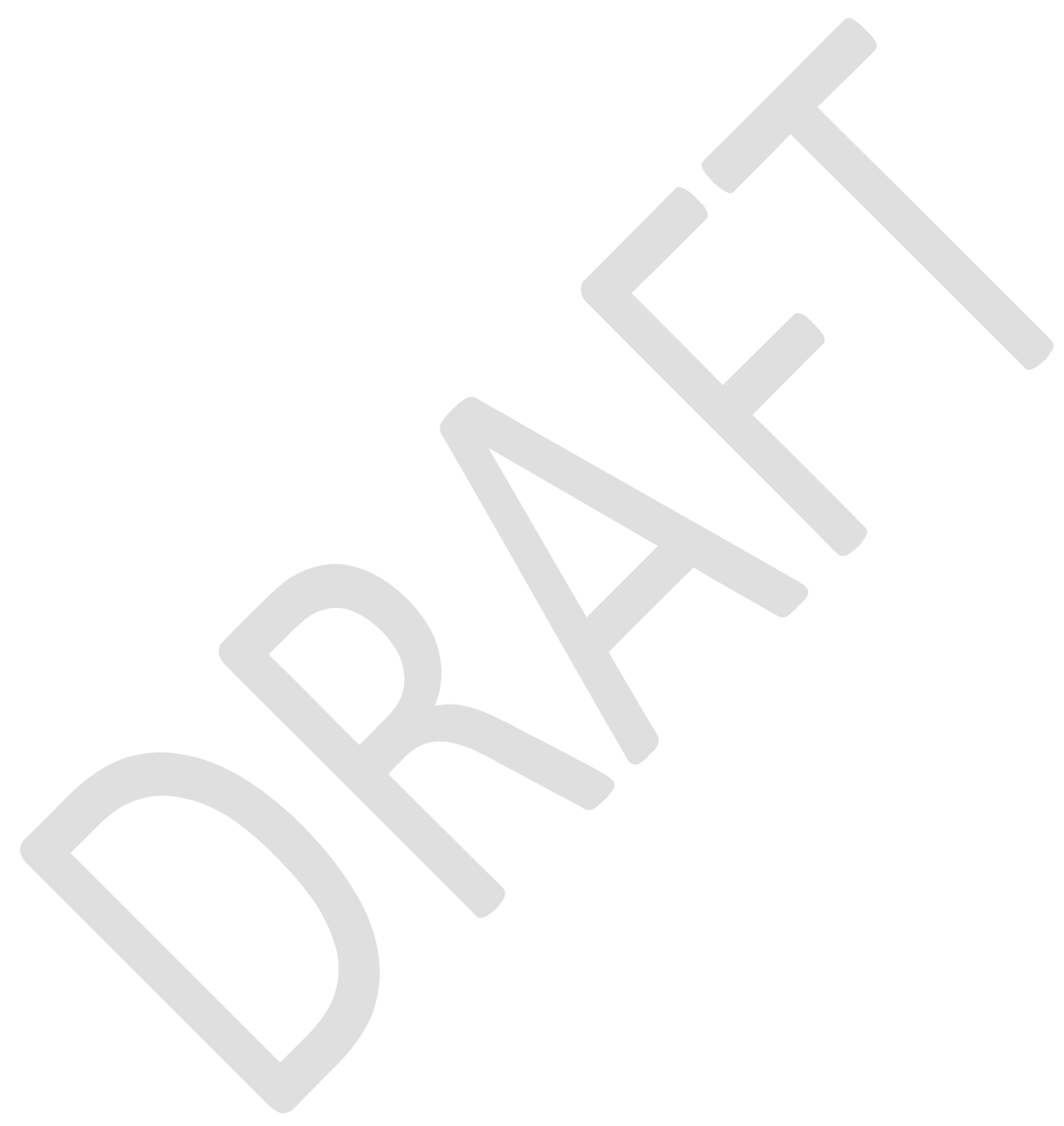


Figure 1: Probability of Enrollment in Remedial Courses by ACT Subject Score
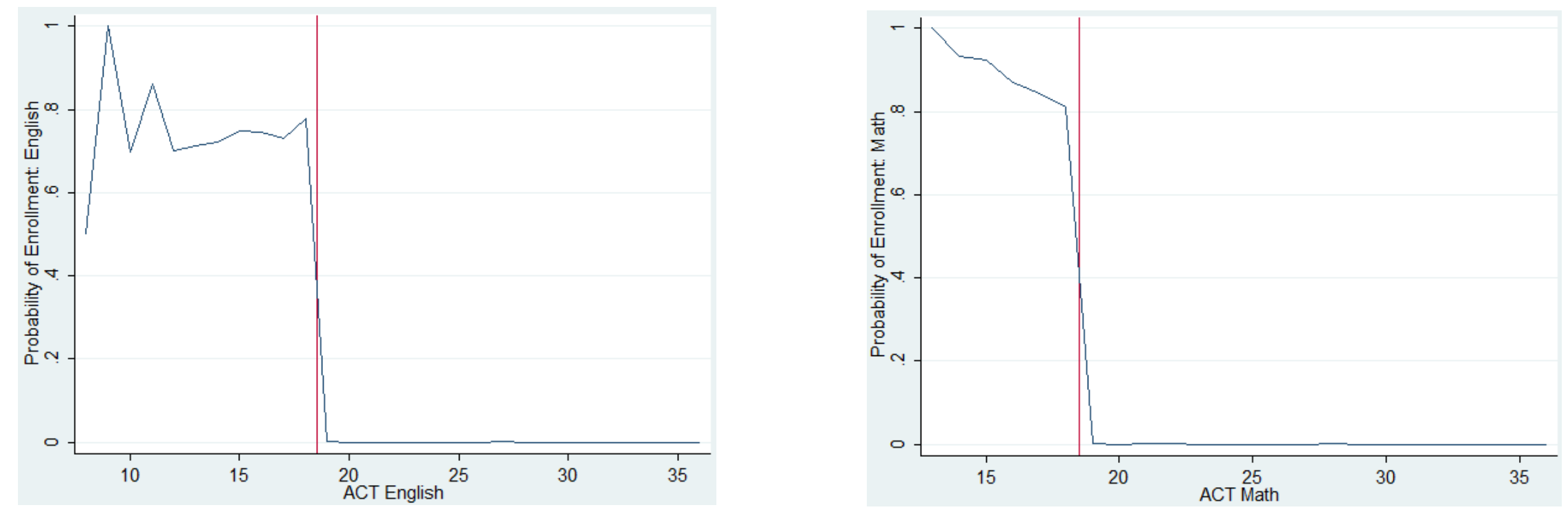

Note: Each graph represents the mean probability of enrollment in remedial courses for each subject. 
Our methods for dealing with noncompliance are similar to that of Calcagno and Long (2008), who implement both an intent-to-treat (ITT) estimate for the remediation policy at Florida community colleges and an instrumental variable (IV) approach to account for noncompliance with recommendations. As Calcagno and Long (2008) explain, using a standard OLS equation to explain the effects of treatment with the divergence between assignment $\left(\mathrm{D}_{i}\right)$ and actually enrolling in remedial coursework $\left(T_{i}\right)$ is an Intent-to-Treat estimate. This yields the following regression model to estimate the causal effect of remediation in Equation 1:

$$
\text { (1) } \quad Y_{i}=\alpha+\beta_{1} D_{i}+\beta_{2} A_{i}+\beta_{3} X_{i}+\varepsilon_{i}
$$

where $\mathrm{D}$ is the is an indicator for assignment to remediation, $A_{i}$ is student $i$ s score on the ACT subject of interest, $\mathrm{Y}_{i}$ is the variable of interest, $\mathrm{X}$ is a vector of observable covariates for student $i$, and $\varepsilon_{i}$ is an error term. A regression of Equation 1 yields the aforementioned ITT estimate of the remediation policy. This allows us to gain an understanding of what the policy's effect would be with strict adherence to the rating rules. This does not provide us with a true estimate of the treatment for the full sample of students and the wide band sample, as it does not include all students who are receiving the treatment. However, this does provide a seemingly accurate estimate of the impact of remediation on students in our narrow band sample.

In order to address noncompliance associated with a fuzzy RD is using an IV approach (Jacob et al, 2012; Calcagno \& Long, 2008). In using an IV approach with the RD design, we use the probability of assignment to remediation as an instrument for enrolling in remediation. With an IV and $\mathrm{RD}$ approach to estimate the effects of treatment in a fuzzy RD, we must carry out a two-stage least squares (2SLS) method. Stage 1 of our 2SLS approach is represented in Equation 2:

$$
\text { (2) } \mathrm{T}_{\mathrm{i}}=\alpha+\gamma_{1} \mathrm{D}_{\mathrm{i}}+\gamma_{2} A_{i}+\gamma_{3} \mathrm{X}_{\mathrm{i}}+\varepsilon_{\mathrm{i}}
$$


where $\mathrm{T}$ is the treatment status, $\mathrm{D}$ is an indicator for assignment to remediation, $\mathrm{A}_{\mathrm{i}}$ represents student $i$ s score on the ACT subject of interest, and $\mathrm{X}$ is a vector of student level covariates. We use a probit model to predict the probability of enrolling in remediation given a student's ACT composite and subject score, along with a student's observable characteristics. Following our first stage equation, we are able to estimate the causal effect of remediation using our second stage equation represented in Equation 3:

$$
\text { (3) } Y_{i}=\alpha+\beta_{1} \widehat{T}_{i}+\beta_{2} f\left(A_{i}\right)+\beta_{3} X_{i}+\varepsilon_{i}
$$

where $\beta_{1}$ is the causal effect of remedial courses on the outcome of interest, Y. This provides us with an unbiased estimate of the local average treatment effect (LATE), which is the impact of the remediation policy on the students assigned to remediation by the cutoff score and actually enrolled and those students who avoided remediation and did not participate as crossovers (Imbens \& Angrist, 1994; Angrist, Imbens, \& Rubin, 1996; Calcagno \& Long, 2008; Jacob et al, 2012).

Essentially, LATE estimates the effect for students who were recommended for remediation by the ACT cutoff score policy.

In our analysis, the wide band sample experiences higher levels of noncompliance, whereas the narrow band sample experiences much lower levels of non-compliance. We assume that these lower levels of noncompliance in the narrow band allows for accurate estimates of the impact of remediation using a simple OLS design rather than the IV method described above. With these methods in mind, we now turn to the estimation of the parameters of interest.

\section{Estimation of Student Outcomes}

The remediation policy at the University of Arkansas is designed to improve the academic outcomes for students who lack adequate preparation prior to enrolling. Because of that we have focused on analyzing the impact of remediation on both short and long-term academic outcomes. As stated earlier, we have 6 outcomes of interest: 
- Cumulative GPA

- Fall-to-Spring first year persistence

- Fall-to-Fall persistence

- Graduation in 4 years

- Graduation in 6 years

The first two outcomes are continuous, which we estimate using OLS models. The final four outcomes are binary, therefore, we use a maximum likelihood probit model to estimate the impact of remediation. As described earlier, our data includes multiple student-level covariates in addition to ACT scores and outcome variables of interest.

Finally, we test the sensitivity of our estimates of the causal impact of remediation to different subsamples of students. To do so, we use two different bandwidths surrounding the cutoff value for each subject. Our estimates include models that include the full sample of students with ACT scores, both with and without control variables. We also include a wide band sample, covering students who scored 17 and 18 on the section and students scoring 19 and 20 on the section. The final subsample is the narrow band, comparing students who scored just below the cutoff score (18) to those scoring at the cutoff score (19).

In Table 4 below, we present the difference-in-difference means for raw outcomes by subject and by analytic sample size. As expected, the differences for the full sample show statistically significant negative estimates for remediation in both English and math. For math in the narrow sample, we see a highly statistically significant and negative result for graduating in 4 years and marginally significant and negative results for cumulative GPA and graduating in 6 years. These differences are the same for the wide band sample, but all three are all highly statistically significant. The narrow sample in English yields one statistically significant result, but it is marginally significant and negative against remediation on graduating in 4 years. The wide sample for English yields a statistically significant result on 4-year graduation and a marginally significant result on graduating in 6 years. It is important to note that these estimates do not control for demographics and therefore 
cannot be interpreted as true impacts of remediation. The following section shows a complete analysis of remediation.

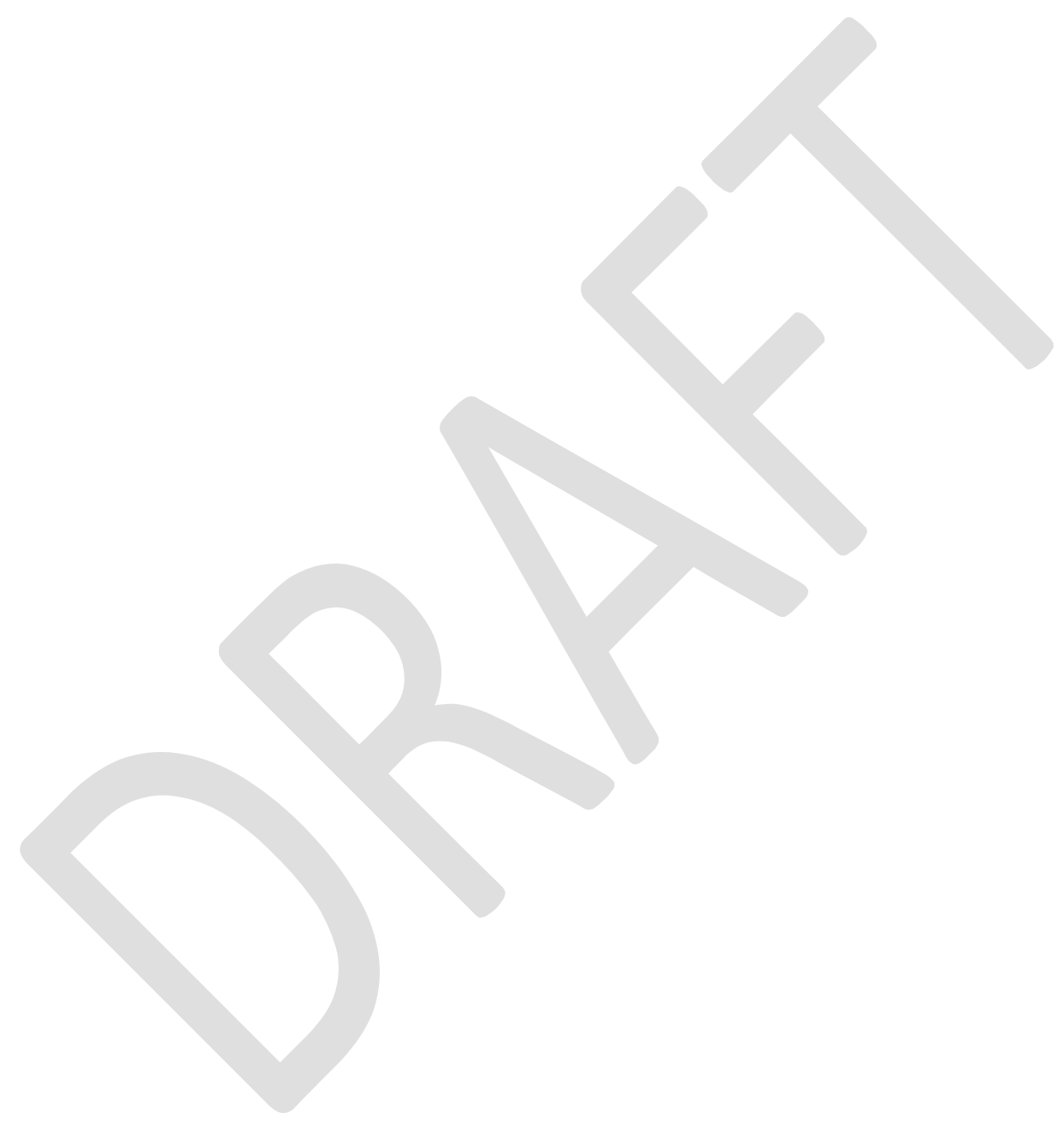


Table 4: Difference-in-Difference Means by subject and sample

\begin{tabular}{|c|c|c|c|c|c|c|c|c|c|}
\hline \multirow{2}{*}{ Variable } & \multicolumn{3}{|c|}{ Band around cutoff (full sample) } & \multicolumn{3}{|c|}{ Band around cutoff (18 v. 19) } & \multicolumn{3}{|c|}{ Band around cutoff (17/18 v. 19/20) } \\
\hline & All below & All above & Difference & 18 & 19 & Difference & $17 / 18$ & $19 / 20$ & Difference \\
\hline \multicolumn{10}{|l|}{$M A T H E M A T I C S$} \\
\hline Graduated in 4 years & 0.18 & 0.39 & $-0.21 * * *$ & 0.19 & 0.24 & $-0.05^{* * *}$ & 0.19 & 0.24 & $-0.04 * * *$ \\
\hline Graduated in 6 years & 0.40 & 0.62 & $-0.05^{* * *}$ & 0.42 & 0.47 & $-0.05^{*}$ & 0.41 & 0.47 & $-0.06 * * *$ \\
\hline Fall-to-Spring Persistence & 0.89 & 0.93 & $-0.04^{* * *}$ & 0.89 & 0.90 & -0.01 & 0.89 & 0.89 & 0.00 \\
\hline $\begin{array}{l}\text { Fall-to-Fall (one year) } \\
\text { Persistence }\end{array}$ & 0.74 & 0.83 & $-0.09 * * *$ & 0.74 & 0.76 & -0.02 & 0.75 & 0.76 & -0.01 \\
\hline \multicolumn{10}{|l|}{$*_{\mathrm{p}}<0.1, *^{*} \mathrm{p}<0.05, * * * \mathrm{p}<0.01$} \\
\hline Observations & 2,791 & 34,504 & & 1,338 & 1,702 & & 2,220 & 3,642 & \\
\hline Cumulative GPA & 2.37 & 2.89 & $-0.52^{* * *}$ & 2.37 & 2.41 & -0.04 & 2.37 & 2.42 & -0.05 \\
\hline Graduated in 4 years & 0.18 & 0.38 & $-0.20 * * *$ & 0.16 & 0.20 & $-0.04 *$ & 0.17 & 0.21 & $-0.04 * *$ \\
\hline Graduated in 6 years & 0.42 & 0.61 & $-0.19 * * *$ & 0.40 & 0.43 & 0.00 & 0.40 & 0.41 & $-0.01 *$ \\
\hline Fall-to-Spring Persistence & 0.90 & 0.93 & $-0.03^{* * *}$ & 0.89 & 0.89 & 0.00 & 0.89 & 0.89 & 0.00 \\
\hline $\begin{array}{l}\text { Fall-to-Fall (one year) } \\
\text { Persistence }\end{array}$ & 0.75 & 0.83 & $-0.08^{* * *}$ & 0.74 & 0.74 & 0.00 & 0.74 & 0.74 & 0.00 \\
\hline \multicolumn{10}{|l|}{${ }^{*} \mathrm{p}<0.1,{ }^{* *} \mathrm{p}<0.05, * * * \mathrm{p}<0.01$} \\
\hline Observations & 1,366 & 35,928 & & 563 & 1,128 & & 894 & 3,015 & \\
\hline
\end{tabular}




\section{Analysis \& Results}

In this section, we discuss the estimated impact of remediation on five outcomes. The short-term outcomes we examine are fall-to-spring (first year) retention and fall-to-fall retention following remediation. If the remedial program at the University of Arkansas accomplishes the stated goals, we would expect that students undergoing remediation would be more successful at persisting into the second semester of college and into their second year of college compared to their non-remediated peers. Therefore, we estimate the probability of persisting past the first semester and first year after remediation in both subjects. This is an especially prescient outcome as one of the most common criticisms of remedial coursework is that it is an unnecessary burden that discourages persistence by increasing the hurdles to college courses for students who are already on the margin (Deil-Amen \& Rosenbaum, 2002; Rosenbaum, 2001).

The long-term outcomes we investigate are the probability of graduating in 4 or 6 years and student's cumulative GPA. Increasing the amount of requirements for marginal students could decrease the probability of graduation by increasing requirements students must meet to enroll in courses needed to graduate. Requiring students to enroll in remedial coursework may impose delays on graduation, making it highly likely that students undergoing remediation and delaying their entrance into credit-bearing coursework will be less likely to graduate in 4 years. While this seems to be a negative result for remediation, the cost of spending more money to stay in college and finish a degree is outweighed by the benefits of earning a college degree rather than not completing college (College Board, 2010).

Tables 5 and 6 show the estimated impacts of math and English remediation respectively. Each row focuses on a different outcome, with each column representing a different method, with the corresponding label for the method and sample. To estimate the binary outcomes, we use a probit model to estimate the impact of remediation and report marginal effects at mean values. We use OLS estimates for the continuous variables. In the results, ITT represents the intent-to-treat 
estimates for the full sample and wide band sample analyses and IV represents the instrumental variable estimates for the full sample and wide sample analyses.

In all estimates we include controls for gender, race/ethnicity, Pell Grant eligibility (used as a proxy for socio-economic status), a categorical variable for the level of expected family contribution, a categorical variable for parent's education levels, high school GPA, and a categorical variable for cohort year. In order to conduct an RD estimate, we follow the steps from Jacob et al (2012) in centering and creating an interaction term to analyze the difference in slopes of the fitted regression lines on the treatment and control students. The expectation is that we will find a less steep line for treatment students, showing the impact of remediation accounting for baseline demographics and achievement. The full regression outputs can be found in Appedices 1-3.

Table 5 below details the impacts of math remediation on educational outcomes. For the full sample of students, we see a marginally significant, negative impact on the ITT estimate of graduating in 4 years. This significance disappears when we run our IV analysis on 4-year graduation, however, the result is still negative. We do see a positive outcome for fall-to-fall retention in the IV estimate that is significant at the 5 percent level. For the wide band sample, we see negative impacts of remediation for fall-to-spring retention and 4 year graduation that are both significant at the 5 percent level. The negative result on 4-year graduation remains in the IV estimates for the wide sample, but is only marginally significant. These results intuitively make sense, as the requirement to complete remediation prior to enrolling in courses counting towards graduation would make it more difficult to graduate in 4 years. The narrow band sample results have a lone statistically significant result (at the 5 percent level) on fall-to-spring retention. Remediated math students have a 4.8 percent lower probability of persisting to their second semester than their non-remediated counterparts. This provides some evidence of the discouragement effect characterized by DeilAmen and Rosenbaum (2002). These results follow those of earlier remediation studies that are not 
optimistic in favor of remediation (Bettinger \& Long, 2006). In fact, the results for the narrow band that would provide the most accurate estimates of the impact of remediation would support criticisms of remediation.

The impacts of English remediation are detailed in Table 6. The IT'T estimates for the full sample show a negative result on 4-year graduation, similar to the results for math. However, the IV estimates for the impacts of remediation are positive and significant at the 99 percent level for Cumulative GPA, fall-to-spring retention, and fall-to-fall retention. The result for 4-year graduation switches from negative to positive and becomes statistically indistinguishable from zero. For the wide band sample, all of the impacts are small and negative as well insignificant. However, the 4-year graduation rate is a statistically significant, negative result (at the 95 percent level) in the ITT model. Students remediated in English have 7.3 percent lower probability of graduating in 4 years than their non-remediated peers. The narrow band results in English are all negative, but are statistically indistinguishable from zero.

The results for English are less negative and seemingly positive in the full sample IV estimates. However, this could be due to the policy in place at the University of Arkansas. Students can be placed in remediation at the discretion of their introductory-level professor based on a writing sample, regardless of ACT score. This could lead to higher ability students being placed in remediation and could skew the results of the causal estimates of remediation for English. 
Table 5: Impact of Mathematics Remediation on Educational Outcomes

\begin{tabular}{lccccc}
\hline & \multicolumn{2}{c}{ All Students } & \multicolumn{2}{c}{ Wide Band } & Narrow Band \\
& ITT & IV & ITT & IV & $(5)$ \\
\hline \multirow{2}{*}{ Cumulative GPA } & $(1)$ & $(2)$ & $(3)$ & $(4)$ & 0.040 \\
& -0.020 & -0.016 & -0.008 & 0.033 & $(0.072)$ \\
\hline \multirow{2}{*}{ Fall-to-Spring Retention } & $(0.032)$ & $(0.007)$ & $(0.044)$ & $(0.068)$ & $-0.048^{* *}$ \\
\hline \multirow{2}{*}{ Fall-to-Fall Retention } & -0.002 & 0.010 & $-0.038^{* *}$ & -0.025 & $(0.022)$ \\
\hline \multirow{2}{*}{ Graduate in 4 Years } & $(0.058)$ & $(0.009)$ & $(0.014)$ & $(0.021)$ & -0.020 \\
& 0.010 & $0.031 * *$ & -0.020 & -0.008 & $(0.031)$ \\
\hline \multirow{2}{*}{ Graduate in 6 Years } & $(0.011)$ & $(0.014)$ & $(0.019)$ & $(0.031)$ & -0.049 \\
& $-0.038^{*}$ & -0.024 & $-0.048^{* *}$ & $-0.058^{*}$ & $(0.033)$ \\
\hline Observations & $(0.022)$ & $(0.028)$ & $(0.022)$ & $(0.034)$ & 0.039 \\
\hline
\end{tabular}

*** $\mathrm{p}<0.01,{ }^{* *} \mathrm{p}<0.05,{ }^{*} \mathrm{p}<0.1$

Note: Observations vary based on outcome measure for all three samples. Cumulative GPA observations for full sample is 17,212; observations for wide band is 3,174; observations for narrow sample is 1,624. Graduation in 4 years observations for full sample is 24,968; observations for wide sample is 4,330; observations for narrow sample is 2,225. Graduation in 6 years for full sample is 17,419; observations for wide sample 3,217; observations for narrow sample is 1,648. 
Table 6: Impact of English Remediation on Educational Outcomes

\begin{tabular}{lccccc}
\hline & \multicolumn{2}{c}{ All Students } & Wide Band & Narrow Band \\
& ITT & IV & ITT & IV & $(5)$ \\
& $(1)$ & $(2)$ & $(3)$ & $(4)$ & -0.001 \\
Cumulative GPA & 0.010 & $0.678^{* * *}$ & -0.032 & -0.031 & $(0.117)$ \\
\hline \multirow{2}{*}{ Fall-to-Spring Retention } & $(0.042)$ & $(0.177)$ & $(0.066)$ & $(0.102)$ & -0.035 \\
\hline \multirow{2}{*}{ Fall-to-Fall Retention } & 0.007 & $0.12)^{* * *}$ & -0.006 & -0.014 & $(0.033)$ \\
\hline \multirow{2}{*}{ Graduate in 4 Years } & $(0.009)$ & $(0.040)$ & $(0.019)$ & $(0.030)$ & -0.037 \\
& 0.013 & $0.368^{* * *}$ & -0.018 & -0.004 & $(0.046)$ \\
\hline \multirow{2}{*}{ Graduate in 6 Years } & $(0.014)$ & $(0.065)$ & $(0.027)$ & $(0.044)$ & -0.020 \\
\hline \multirow{2}{*}{ Observations } & $-0.067 * *$ & 0.130 & $-0.073 * *$ & -0.053 & $(0.044)$ \\
\hline
\end{tabular}

$* * * \mathrm{p}<0.01, * * \mathrm{p}<0.05, * \mathrm{p}<0.1$

Note: Observations vary based on outcome measure for all three samples. Cumulative GPA observations for full sample is 17,212; observations for wide band is 1,956; observations for narrow sample is 864. Graduation in 4 years observations for full sample is 24,968; observations for wide sample is 2,759; observations for narrow sample is 1,181. Graduation in 6 years for full sample is 17,419; observations for wide sample is 1,988 ; observations for narrow sample is 881 . 


\section{Conclusion}

This study provides a preliminary evaluation of Arkansas's post-secondary remediation policy at the University of Arkansas. This study addresses limitations in using a regression discontinuity design to analyze remediation using similar methods to that of Calcagno and Long (2008). We have examined the impact of remediation on nearly 40,000 first-time enrollees at the flagship 4-year institution in the state of Arkansas. This study contributes additional evidence on the effectiveness of postsecondary remediation as measured by both short and long-term academic outcomes. We have shown that remediation is a large investment at the college level and that the literature has shown little in estimating the causal impact of remediation with conflicting results.

The results of this study are mixed, with benefits from English remediation and drawbacks from math remediation. Limiting our analysis to the students immediately surrounding the cutoff score showed no impact from English remediation, but math students were nearly 5 percentage points less likely to persist beyond their first semester of college. Expanding the sample to a wider band of students yielded statistically significant negative results on 4-year graduation rates, a result that makes logical sense given the addition of extra courses that do not count towards graduation. However, there is no statistically significant difference in 6-year graduation rates. This could show that while remediated students were less likely to graduate in 4 years, they stick around and earn a degree at similar rates as non-remediated students. We do find statistically significant positive results on IV estimates for fall-to-fall retention for remediated math students and cumulative GPA, fall-tospring retention, and fall-to-fall retention for remediated English students. The results on persistence for the full sample argue against the discouragement effect put forth by Deil-Amen and Rosenbaum (2002).

Our research examines a large, diverse group of first-time college enrollees and gives an increased perspective on the effects of post-secondary remediation. However, there are shortcomings. Given Arkansas's policy of 4-year universities decreasing their offerings of remedial 
coursework, we lack the information for students who completed their remedial coursework at a 2year institution or how many attempts students may have used to test out of remediation. Also, Arkansas may not be the same as other states in terms of the cutoff to create populations of students who are considered for remediation. The differences in our results compared to Bettinger and Long's analysis in Ohio, Calcagno and Long's analysis in Florida, and Martorell and McFarlin's examination of Texas could all have different cutoffs for remediation that could lead to the different results of post-secondary remediation.

While we find some positive results and some negative results for remediation, these results should be given careful consideration. Our estimates should not be extrapolated beyond the scope of the University examined here or to students well below the cutoff. There very well may be effective remedial programs in place at other campuses in different states. Also, the remedial program at the University of Arkansas could be subject to weaknesses of implementation.

The policy implications of our analysis show that states should be more cognizant of the implementation of the remediation policy. While Arkansas has a strict cutoff for recommendation to remediation, the actual enrollment in remedial coursework varies by subject. If the focus of remediation is to help students who have shown low-levels of achievement, then the policy should avoid exempting students from remediation. The issues created by noncompliance can introduce important consequences to remediation. Also, if the cutoff is a more fluid rating allowing students to opt-in when they score above the cut score, the state should consider a reevaluation of the cutoff to accurately reflect the desired level of preparation for first-time enrollees.

Our analysis has extended the literature on post-secondary remediation. However, it is clear that more information is needed to estimate the true impact of college remediation on students. Also, this research would be most improved by a cost-benefit analysis both for students and 
universities. It would also be helpful to examine the approaches and characteristics of successful remediation policies and evaluate these practices using the most rigorous methods possible. 


\section{References}

Angrist, J. (2001). Estimation of limited-dependent variable models with binary endogenous regressors: Simple strategies for empirical practice. Journal of Business and Economic Statistics, 19(1), $2-28$.

Angrist, J., \& Imbens, G. (1995). Two-stage least squares estimation of average causal effects in models with variable treatment intensity. Journal of the American Statistical Association, 90(430), 431-442.

Angrist, J., Imbens, G., \& Rubin, D. (1996). Identification of causal effects using instrumental variables. Journal of the American Statistical Association, 91(434), 444-472.

Arkansas State Department of Higher Education. (2015). "Remediation Report Fall, Academic Year 2014-15”. https://static.ark.org/eeuploads/adhe/publications/Developmental courseworkiation_Fall_AY_2014-2015.pdf

Armstrong, E.A. \& Hamilton, L.T. (2013). Paying for the Party: How College Maintains Inequality. Cambridge, MA: Harvard University Press

Arum, R. \& Roksa, J. (2011). Academically Adrift: Limited Learning on College Campuses. Chicago, IL: University of Chicago Press.

Attewell, P., Lavin, D., Domina, T., \& Levey, T. (2006). New evidence on college remediation”. Journal of Higher Education, 77(5), 886-924.

Bailey, T.R., Jenkins, D. \& Jaggars, S.S. (2015). Redesigning America's Community Colleges: A Clearer Path to Student Success. Cambridge, MA: Harvard University Press

Battistin, E., \& Rettore, E. (2002). Testing for programme effects in a regression discontinuity design with imperfect compliance. Journal of the Royal Statistical Society, Series A, 165(1), 39-57.

Baum, S., Ma, J., \& Payea, K. (2013). “Education Pays 2013: The Benefits of Higher Education for Individuals and Society”. https://trends.collegeboard.org/sites/default/files/educationpays-2013-full-report.pdf

Bettinger, E., \& Long, B. (2004). Shape up or ship out: The effects of remediation on students at four-year colleges (NBER Working Paper No. 10369). Cambridge, MA: National Bureau of Economic Research.

Bettinger, E., \& Long, B. (2005). Remediation at the community college: Student participation and outcomes. New Directions for Community Colleges, 129(1), 17-26.

Bettinger, E. \& Long, B. (2006). “Addressing the Needs of Under-Prepared Students in Higher Education: Does College Remediation Work?” NBER Working Paper No. 11325.

Boatman, A \& Long, B.T. (2010). "Does Remediation Work for All Students? How the Effects of Postsecondary Remedial and Developmental Courses Vary by Level of Academic Preparation," National Center for Postsecondary Research. http:/ files.eric.ed.gov/fulltext/ED512610.pdf

Breneman, D., \& Haarlow, W. (1998). Remedial education: Costs and consequences. Paper presented at Remediation in Higher Education: A Symposium, Washington, DC.

Bureau of Labor Statistics, U.S. Department of Labor, The Economics Daily, 2008 high school grads and college enrollment on the Internet at http://www.bls.gov/opub/ted/2009/apr/wk4/art03.htm (visited March 15, 2010). 
Calcagno, J.C. \& Long, B.T. (2008). “The Impact of Postsecondary Remediation Using a Regression Discontinuity Approach: Addressing Endogenous Sorting and Noncompliance”. NCPR Working Paper

Campbell, D. (1969). Reforms as experiments. American Psychologist, 24(4), 409-429.

The College Board. (2010). "Lifetime Earnings by Education Level". http://trends.collegeboard.org/education-pays/figures-tables/lifetime-earnings-educationlevel

Dadgar, M. (2012). Essays on the Economics of Community College Students' Academic and Labor Market Success. (Doctoral Dissertation) Retrieved from ProQuest Dissertations and Theses.

Deil-Amen, R., \& Rosenbaum, J. (2002). The unintended consequences of stigma-free remediation. Sociology of Education, 75(3), 249-268.

Greene, J., \& Forster, G. (2003, September). Public high school graduation and college readiness rates in the United States (Manhattan Institute, Center for Civic Information, Education Working Paper, No. 3). New York: Manhattan Institute.

Harlow, C. W. (2003). "Education and Correctional Populations". U.S. Bureau Department of Justice. http://www.bjs.gov/content/pub/pdf/ecp.pdf

Hsu, J. \& Gehring, W.J. (2016). "Measuring Student Success from a Developmental Mathematics Course at an Elite Public Institution". Working Paper.

https://www.sree.org/conferences/2016s/program/downloads/abstracts/1818.pdf

Imbens, G., \& Angrist, J. (1994). "Identification and estimation of local average treatment effects". Econometrica, 62(2), 467-476.

Imbens, G., \& Lemieux, T. (2008). "Regression discontinuity designs: A guide to practice". Journal of Econometrics, 142(2), 615-635.

Jacob, B., \& Lefgren, L. (2004). "Remedial education and student achievement: A regressiondiscontinuity analysis". Review of Economics and Statistics, 86(1), 226-244.

Jacob, R., Zhu, P., Somers, M-A, \& Bloom, H. (2012). “A Practical Guide to Regression Discontinuity”. MDRC Publications. http://www.mdrc.org/publication/practical-guideregression-discontinuity

Kane, T., \& Rouse, C. (1999). The community college: Educating students at the margin between college and work. Journal of Economic Perspectives, 13(1), 63-84.

Lee, D. (2008). Randomized experiments from non-random selection in U.S. House Elections. Journal of Econometrics, 142(2), 675-697.

Lee, D., \& Card, D. (2008). Regression discontinuity inference with specification error. Journal of Econometrics, 142(2), 655-674.

Martorell, P. \& McFarlin, I. (2011). "Help or Hindrance? The Effects of College Remediation on Academic and Labor Market Outcomes". The Review of Economics and Statistics. 93(2), 436-454.

McCrary, J. (2008). Manipulation of the running variable in the regression discontinuity design: A density test. Journal of Econometrics, 142(2), 698-714.

Merisotis, J., \& Phipps, R. (2000). Remedial education in colleges and universities: What's really going on? Review of Higher Education, 24(1), 67-85. 
National Student Clearinghouse. (2015). "National College Completion Rates Continue to Decline". https://nscnews.org/national-college-completion-rates-continue-to-decline/

Office of Program Policy and Government Accountability [OPPAGA]. (2006). Steps can be taken to reduce remediation rates (Report 06-40). Tallahassee: Florida Legislature.

Petrilli, M.J. (2016) "What Ordinary People Know but Elites Won't Admit about College Readiness". EducationNext. http:/ / educationnext.org/what-ordinary-people-know-but-eliteswont-admit-about-college-readiness/

Rosenbaum, J. (2001). Beyond college for all. New York: Russell Sage Foundation.

Scott-Clayton, J \& Rodriguez, O. (2012) “Development, Discouragement, or Diversion? New Evidence on the Effects of College Remediation." NBER Working Paper Series. http://www.nber.org/papers/w18328.

University of Arkansas. (2015). "Placement and Proficiency Tests". https://catalog.uark.edu/undergraduatecatalog/enrollmentservices/placementandproficienc ytests/

U.S. Census Bureau. (2015). "Quick Facts: Arkansas”. http://www.census.gov/quickfacts/table/PST045215/05

Van der Klaauw, W. (2002). Estimating the effect of financial aid offers on college enrollment decisions: A regression-discontinuity approach. International Economic Review, 43(4), 12491287.

Wolfle, J.D. \& Williams, M.R (2014). “The Impact of Developmental Mathematics Courses and Age, Gender, and Race and Ethnicity on Persistence and Academic Performance in Virginia Community Colleges", Community College Journal of Research and Practice, Vol. 38 No 2-3, p. 144-153. 


\section{Appendix 1: Full Sample Regression Output}

Impact of Math Remediation

Appendix 1: Full Sample Regression Output

(1)

(4) (5)

\begin{tabular}{|c|c|c|c|c|c|c|c|c|c|c|c|c|}
\hline VARIABLES & $\begin{array}{c}\text { Fall-to-Fall } \\
\text { Retention } \\
\text { ITT }\end{array}$ & $\begin{array}{c}\text { Fall-to-Fall } \\
\text { Retention } \\
\text { IV }\end{array}$ & $\begin{array}{c}\text { Cumulative } \\
\text { GPA } \\
\text { ITT }\end{array}$ & $\begin{array}{c}\text { Cumulative } \\
\text { GPA } \\
\text { IV }\end{array}$ & $\begin{array}{c}\text { Fall-to- } \\
\text { Spring } \\
\text { Retention } \\
\text { ITT }\end{array}$ & $\begin{array}{c}\text { Fall-to- } \\
\text { Spring } \\
\text { Retention } \\
\text { IV }\end{array}$ & $\begin{array}{c}\text { Graduate } \\
\text { in } 4 \text { Years } \\
\text { ITT }\end{array}$ & $\begin{array}{c}\text { Graduate } \\
\text { in } 4 \text { Years } \\
\text { IV }\end{array}$ & $\begin{array}{c}\text { Graduate in } \\
6 \text { Years } \\
\text { ITT }\end{array}$ & $\begin{array}{c}\text { Graduate } \\
\text { in } 6 \text { Years } \\
\text { IV }\end{array}$ & $\begin{array}{c}\text { Credits } \\
\text { Earned in } \\
4 \text { Years } \\
\text { ITT }\end{array}$ & $\begin{array}{c}\text { Credits } \\
\text { Earned in } \\
4 \text { Years } \\
\text { IV }\end{array}$ \\
\hline \multirow[t]{2}{*}{ math_remedial } & 0.010 & $0.0310^{* *}$ & -0.020 & -0.016 & -0.002 & 0.010 & $-0.0378 *$ & -0.024 & -0.022 & -0.012 & 0.224 & 2.670 \\
\hline & -0.011 & -0.014 & -0.032 & -0.040 & -0.007 & -0.009 & -0.022 & -0.028 & -0.022 & -0.027 & -1.420 & -1.870 \\
\hline \multirow[t]{2}{*}{ act_math_center } & $0.005^{* * *}$ & $0.005^{* * *}$ & $0.016^{* * *}$ & $0.016^{* * *}$ & $0.003^{* * *}$ & $0.003^{* * *}$ & $0.008^{* * *}$ & $0.008^{* * *}$ & $0.006^{* * *}$ & $0.006^{* * *}$ & $1.053^{* * *}$ & $1.075^{* * *}$ \\
\hline & -0.001 & -0.001 & -0.002 & -0.002 & 0.000 & 0.000 & -0.001 & -0.001 & -0.001 & -0.001 & -0.065 & -0.066 \\
\hline \multirow[t]{2}{*}{ act_math_treat_interact } & $-0.0113^{*}$ & -0.003 & -0.014 & -0.013 & $-0.012 * * *$ & -0.007 & -0.009 & -0.003 & -0.009 & -0.006 & $-2.172 * * *$ & -1.222 \\
\hline & -0.006 & -0.007 & -0.017 & -0.020 & -0.004 & -0.005 & -0.013 & -0.015 & -0.012 & -0.014 & -0.837 & -0.975 \\
\hline \multirow[t]{2}{*}{ af_american } & $0.070^{* * *}$ & $0.070^{* * *}$ & -0.039 & -0.039 & $0.051^{* * *}$ & $0.051^{* * *}$ & -0.013 & -0.013 & 0.022 & 0.021 & $8.318^{* * *}$ & $8.273^{* * *}$ \\
\hline & -0.009 & -0.009 & -0.025 & -0.025 & -0.006 & -0.006 & -0.017 & -0.017 & -0.019 & -0.019 & -0.987 & -0.987 \\
\hline \multirow[t]{2}{*}{ hispanic_other } & $0.0189 * *$ & $0.019 * *$ & 0.052 & 0.052 & $0.0124 * *$ & $0.0124 * *$ & -0.021 & -0.021 & $0.0393 *$ & $0.0393 *$ & $3.995^{* * *}$ & $4.013 * * *$ \\
\hline & -0.009 & -0.009 & -0.032 & -0.032 & -0.006 & -0.006 & -0.018 & -0.018 & -0.023 & -0.023 & -0.947 & -0.947 \\
\hline \multirow[t]{2}{*}{ asian } & $0.070^{* * *}$ & $0.070^{* * *}$ & -0.050 & -0.050 & $0.034 * * *$ & $0.034 * * *$ & 0.002 & 0.002 & 0.003 & 0.003 & $6.129 * * *$ & $6.124 * * *$ \\
\hline & -0.014 & -0.014 & -0.032 & -0.032 & -0.009 & -0.009 & -0.021 & -0.021 & -0.024 & -0.024 & -1.304 & -1.305 \\
\hline \multirow[t]{2}{*}{ other_race } & $-0.033^{* * *}$ & $-0.033^{* * *}$ & $-0.083^{* * *}$ & $-0.083^{* * *}$ & -0.004 & -0.004 & $-0.069 * * *$ & $-0.069 * * *$ & $-0.0689 * * *$ & $-0.069 * * *$ & $-3.954 * * *$ & $-3.963 * * *$ \\
\hline & -0.009 & -0.009 & -0.028 & -0.028 & -0.006 & -0.006 & -0.016 & -0.016 & -0.020 & -0.020 & -0.967 & -0.968 \\
\hline \multirow[t]{2}{*}{ gender_recode } & $0.014 * * *$ & $0.013^{* * *}$ & $0.207 * * *$ & $0.207 * * *$ & 0.003 & 0.003 & $0.103^{* * *}$ & $0.103^{* * *}$ & $0.033^{* * *}$ & $0.032 * * *$ & $3.417 * * *$ & $3.407 * * *$ \\
\hline & -0.004 & -0.004 & -0.011 & -0.011 & -0.003 & -0.003 & -0.007 & -0.007 & -0.008 & -0.008 & -0.419 & -0.419 \\
\hline \multirow[t]{2}{*}{ pell_grant_rec } & 0.015 & 0.015 & $-0.062 * *$ & $-0.062^{* *}$ & $0.021 * * *$ & $0.020^{* * *}$ & $-0.052 * * *$ & $-0.052 * * *$ & $-0.071^{* * *}$ & $-0.071 * * *$ & $-2.239 * *$ & $-2.245^{* *}$ \\
\hline & -0.009 & -0.009 & -0.027 & -0.027 & -0.007 & -0.007 & -0.015 & -0.015 & -0.018 & -0.018 & -1.112 & -1.112 \\
\hline \multirow[t]{2}{*}{ 1.efc_recode } & $-0.070 * * *$ & $-0.070 * * *$ & $-0.099 * * *$ & $-0.099 * * *$ & $-0.047 * * *$ & $-0.047 * * *$ & $-0.059 * * *$ & $-0.059 * * *$ & -0.024 & -0.024 & $-5.713 * * *$ & $-5.721 * * *$ \\
\hline & -0.012 & -0.012 & -0.033 & -0.033 & -0.010 & -0.010 & -0.018 & -0.018 & -0.022 & -0.022 & -1.280 & -1.280 \\
\hline \multirow[t]{2}{*}{ 2.efc_recode } & $-0.036^{* * *}$ & $-0.036^{* * *}$ & $-0.103^{* * *}$ & $-0.103^{* * *}$ & $-0.015^{* * *}$ & $-0.015^{* * *}$ & $-0.054 * * *$ & $-0.054 * * *$ & $-0.068^{* * *}$ & $-0.068 * * *$ & $-4.359 * * *$ & $-4.365^{* * *}$ \\
\hline & -0.006 & -0.006 & -0.018 & -0.018 & -0.004 & -0.004 & -0.011 & -0.011 & -0.014 & -0.014 & -0.671 & -0.671 \\
\hline \multirow[t]{2}{*}{ 3.efc_recode } & $-0.015^{* *}$ & $-0.015^{* *}$ & $-0.084 * * *$ & $-0.084 * * *$ & -0.005 & -0.005 & $-0.035^{* * *}$ & $-0.035 * * *$ & $-0.049 * * *$ & $-0.049 * * *$ & $-2.331 * * *$ & $-2.330 * * *$ \\
\hline & -0.006 & -0.006 & -0.017 & -0.017 & -0.004 & -0.004 & -0.010 & -0.010 & -0.013 & -0.013 & -0.621 & -0.621 \\
\hline \multirow[t]{2}{*}{ 4.efc_recode } & $0.010^{*}$ & $0.010^{*}$ & $-0.041 * * *$ & $-0.041 * * *$ & 0.004 & 0.004 & -0.007 & -0.006 & 0.004 & 0.004 & 0.500 & 0.500 \\
\hline & -0.006 & -0.006 & -0.016 & -0.016 & -0.004 & -0.004 & -0.010 & -0.010 & -0.013 & -0.013 & -0.599 & -0.599 \\
\hline \multirow[t]{2}{*}{ 1.parent_ed } & 0.022 & 0.019 & $-0.050^{*}$ & $-0.050^{*}$ & 0.006 & 0.005 & $-0.057 * * *$ & $-0.057 * * *$ & $-0.035^{*}$ & $-0.035^{*}$ & -1.938 & -1.932 \\
\hline & -0.017 & -0.017 & -0.029 & -0.029 & -0.011 & -0.011 & -0.020 & -0.020 & -0.021 & -0.021 & -1.647 & -1.647 \\
\hline \multirow[t]{2}{*}{ 2.parent_ed } & $0.065^{* * *}$ & $0.062 * * *$ & $0.052 *$ & $0.052 *$ & $0.024 * *$ & $0.023 * *$ & -0.020 & -0.019 & $0.033^{*}$ & $0.033^{*}$ & $4.409 * * *$ & $4.426^{* * *}$ \\
\hline & -0.016 & -0.016 & -0.027 & -0.027 & -0.011 & -0.011 & -0.020 & -0.020 & -0.020 & -0.020 & -1.608 & -1.608 \\
\hline 3.parent_ed & $0.088^{* * *}$ & $0.085^{* * *}$ & $0.144 * * *$ & $0.143^{* * *}$ & $0.036^{* * *}$ & $0.034 * * *$ & $0.040^{* *}$ & $0.041 * *$ & $0.087 * * *$ & $0.087^{* * *}$ & $8.048^{* * *}$ & $8.063^{* * *}$ \\
\hline
\end{tabular}

\footnotetext{
Ensuring College Readiness
}

[Type text] 


\begin{tabular}{|c|c|c|c|c|c|c|c|c|c|c|c|c|}
\hline \multirow{3}{*}{ hs_gpa } & -0.016 & -0.016 & -0.026 & -0.026 & -0.011 & -0.011 & -0.020 & -0.019 & -0.020 & -0.019 & -1.583 & -1.583 \\
\hline & $0.163^{* * *}$ & $0.163^{* * *}$ & $0.958 * * *$ & $0.958 * * *$ & $0.063 * * *$ & $0.063^{* * *}$ & $0.397 * * *$ & $0.397 * * *$ & $0.389 * * *$ & $0.389 * * *$ & $35.71 * * *$ & $35.71^{* * *}$ \\
\hline & -0.006 & -0.006 & -0.017 & -0.017 & -0.004 & -0.004 & -0.010 & -0.010 & -0.012 & -0.012 & -0.625 & -0.625 \\
\hline Observations & 37,163 & 37,163 & 17,212 & 17,212 & 37,163 & 37,163 & 24,968 & 24,968 & 17,419 & 17,419 & 37,163 & 37,163 \\
\hline R-squared & & & 0.361 & 0.361 & & & & & & & 0.383 & 0.383 \\
\hline
\end{tabular}

Standard errors in

parentheses

${ }^{* * *} \mathrm{p}<0.01, * * \mathrm{p}<0.05, *$

$\mathrm{p}<0.1$

NOTE: All predictors for binary outcomes at mean values 


\section{Impact of English Remediation}

\begin{tabular}{|c|c|c|c|c|c|c|c|c|c|c|c|c|}
\hline & $\begin{array}{l}\quad(1) \\
\text { Fall-to-Fall } \\
\text { Retention }\end{array}$ & $\begin{array}{l}\text { Fall-to-Fall } \\
\text { Retention }\end{array}$ & $\begin{array}{c}\text { Cumulative } \\
\text { GPA }\end{array}$ & $\begin{array}{c}\text { (4) } \\
\text { Cumulative } \\
\text { GPA }\end{array}$ & $\begin{array}{c}(5) \\
\text { Fall-to- } \\
\text { Spring } \\
\text { Retention }\end{array}$ & $\begin{array}{c}(6) \\
\text { Fall-to- } \\
\text { Spring } \\
\text { Retention }\end{array}$ & $\begin{array}{c}(7) \\
\text { Graduate in } \\
4 \text { Years }\end{array}$ & $\begin{array}{c}(8) \\
\text { Graduate in } \\
4 \text { Years }\end{array}$ & $\begin{array}{c}\text { Graduate in } \\
6 \text { Years }\end{array}$ & $\begin{array}{l}\text { Graduate } \\
\text { in } 6 \text { Years }\end{array}$ & $\begin{array}{c}\text { Credits in } 4 \\
\text { Years }\end{array}$ & $\begin{array}{l}(12) \\
\text { Credits in } 4 \\
\text { Years }\end{array}$ \\
\hline VARIABLES & ITT & IV & ITT & IV & ITT & IV & ITT & IV & ITT & IV & ITT & IV \\
\hline \multirow[t]{2}{*}{ engl_remedial } & 0.013 & $0.368^{* * *}$ & 0.010 & $0.678^{* * *}$ & 0.007 & $0.129 * * *$ & $-0.0670^{* *}$ & 0.130 & -0.028 & 0.031 & -0.577 & 10.230 \\
\hline & -0.014 & -0.065 & -0.042 & -0.177 & -0.009 & -0.040 & -0.029 & -0.138 & -0.029 & -0.132 & -1.793 & -7.985 \\
\hline \multirow[t]{2}{*}{ act_eng_center } & $0.004 * * *$ & $0.004 * * *$ & $0.017 * * *$ & $0.016^{* * *}$ & $0.002 * * *$ & $0.002 * * *$ & $0.007 * * *$ & $0.007 * * *$ & $0.003^{* * *}$ & $0.003^{* * *}$ & $0.691 * * *$ & $0.688^{* * *}$ \\
\hline & -0.001 & -0.001 & -0.001 & -0.001 & 0.000 & 0.000 & -0.001 & -0.001 & -0.001 & -0.001 & -0.053 & -0.053 \\
\hline \multirow[t]{2}{*}{ act_eng_treat_interact } & $-0.011 * *$ & $-0.009 * *$ & $-0.058 * * *$ & $-0.050 * * *$ & $-0.007 *$ & $-0.007 * *$ & $-0.035^{* * *}$ & $-0.019 * *$ & $-0.022 * *$ & $-0.016^{*}$ & $-2.840 * * *$ & $-2.576 * * *$ \\
\hline & -0.005 & -0.004 & -0.014 & -0.011 & -0.004 & -0.003 & -0.011 & -0.009 & -0.011 & -0.009 & -0.667 & -0.543 \\
\hline \multirow[t]{2}{*}{ af_american } & $0.068^{* * *}$ & $0.038^{* * *}$ & $-0.055^{* *}$ & $-0.114 * * *$ & $0.050^{* * *}$ & $0.038^{* * *}$ & -0.021 & -0.029 & 0.012 & 0.009 & $7.542^{* * *}$ & $6.792 * * *$ \\
\hline & -0.009 & -0.010 & -0.025 & -0.028 & -0.006 & -0.007 & -0.017 & -0.019 & -0.019 & -0.022 & -0.983 & -1.084 \\
\hline \multirow[t]{2}{*}{ hispanic_other } & $0.0198^{* *}$ & 0.009 & $0.0575^{*}$ & 0.035 & $0.0129 * *$ & 0.009 & -0.019 & -0.022 & 0.0389* & 0.038 & $4.068^{* * *}$ & $3.809 * * *$ \\
\hline & -0.009 & -0.009 & -0.032 & -0.033 & -0.006 & -0.006 & -0.018 & -0.019 & -0.023 & -0.023 & -0.945 & -0.959 \\
\hline \multirow[t]{2}{*}{ asian } & $0.0759 * * *$ & $0.0627^{* * *}$ & -0.028 & -0.052 & $0.0373 * * *$ & $0.0324 * * *$ & 0.015 & 0.010 & 0.009 & 0.007 & $7.396^{* * *}$ & $7.086^{* * *}$ \\
\hline & -0.014 & -0.014 & -0.032 & -0.033 & -0.009 & -0.009 & -0.021 & -0.021 & -0.024 & -0.025 & -1.314 & -1.328 \\
\hline \multirow[t]{2}{*}{ other_race } & $-0.033 * * *$ & $-0.060 * * *$ & $-0.080 * * *$ & $-0.133 * * *$ & -0.003 & $-0.014 * *$ & $-0.069 * * *$ & $-0.076 * * *$ & $-0.070 * * *$ & $-0.072 * * *$ & $-3.918^{* * *}$ & $-4.584 * * *$ \\
\hline & -0.009 & -0.010 & -0.028 & -0.031 & -0.006 & -0.006 & -0.016 & -0.018 & -0.020 & -0.022 & -0.970 & -1.073 \\
\hline \multirow[t]{2}{*}{ gender_recode } & 0.005 & $0.010^{* * *}$ & $0.171 * * *$ & $0.180^{* * *}$ & -0.001 & 0.001 & $0.083^{* * *}$ & $0.085^{* * *}$ & $0.018^{* *}$ & $0.019 * *$ & $1.381 * * *$ & $1.506^{* * *}$ \\
\hline & -0.004 & -0.004 & -0.010 & -0.011 & -0.002 & -0.003 & -0.006 & -0.007 & -0.008 & -0.008 & -0.399 & -0.407 \\
\hline \multirow[t]{2}{*}{ pell_grant_rec } & 0.015 & 0.014 & $-0.064 * *$ & $-0.065^{* *}$ & $0.020 * * *$ & $0.020 * * *$ & $-0.053^{* * *}$ & $-0.053 * * *$ & $-0.072 * * *$ & $-0.073^{* * *}$ & $-2.325^{* *}$ & $-2.342 * *$ \\
\hline & -0.009 & -0.009 & -0.027 & -0.027 & -0.007 & -0.006 & -0.015 & -0.015 & -0.018 & -0.018 & -1.109 & -1.109 \\
\hline \multirow[t]{2}{*}{ 1.efc_recode } & $-0.071 * * *$ & $-0.065^{* * *}$ & $-0.102 * * *$ & $-0.092 * * *$ & $-0.048^{* * *}$ & $-0.046^{* * *}$ & $-0.062 * * *$ & $-0.060 * * *$ & -0.025 & -0.023 & $-6.012 * * *$ & $-5.870 * * *$ \\
\hline & -0.012 & -0.012 & -0.032 & -0.032 & -0.010 & -0.010 & -0.018 & -0.018 & -0.022 & -0.022 & -1.279 & -1.281 \\
\hline \multirow[t]{2}{*}{ 2.efc_recode } & $-0.037 * * *$ & $-0.028^{* * *}$ & $-0.105^{* * *}$ & $-0.089 * * *$ & $-0.016^{* * *}$ & $-0.013^{* * *}$ & $-0.057 * * *$ & $-0.054 * * *$ & $-0.068^{* * *}$ & $-0.067 * * *$ & $-4.608^{* * *}$ & $-4.398^{* * *}$ \\
\hline & -0.006 & -0.007 & -0.018 & -0.019 & -0.004 & -0.004 & -0.011 & -0.011 & -0.014 & -0.014 & -0.673 & -0.683 \\
\hline \multirow[t]{2}{*}{ 3.efc_recode } & $-0.016 * * *$ & -0.008 & $-0.083 * * *$ & $-0.067 * * *$ & -0.005 & -0.003 & $-0.036 * * *$ & $-0.033 * * *$ & $-0.048^{* * *}$ & $-0.047 * * *$ & $-2.471 * * *$ & $-2.264 * * *$ \\
\hline & -0.006 & -0.006 & -0.016 & -0.017 & -0.004 & -0.004 & -0.010 & -0.011 & -0.013 & -0.013 & -0.623 & -0.633 \\
\hline \multirow[t]{2}{*}{ 4.efc_recode } & 0.009 & $0.0160 * * *$ & $-0.0404^{* *}$ & -0.026 & 0.003 & 0.006 & -0.008 & -0.005 & 0.005 & 0.006 & 0.237 & 0.419 \\
\hline & -0.006 & -0.006 & -0.016 & -0.016 & -0.004 & -0.004 & -0.010 & -0.011 & -0.013 & -0.013 & -0.601 & -0.610 \\
\hline \multirow[t]{2}{*}{ 1.parent_ed } & 0.021 & $0.053^{* * *}$ & $-0.050^{*}$ & -0.014 & 0.006 & 0.018 & $-0.059 * * *$ & $-0.051 * *$ & $-0.037^{*}$ & -0.035 & -2.085 & -1.464 \\
\hline & -0.017 & -0.019 & -0.029 & -0.030 & -0.011 & -0.013 & -0.020 & -0.021 & -0.021 & -0.022 & -1.654 & -1.703 \\
\hline \multirow[t]{2}{*}{ 2.parent_ed } & $0.064 * * *$ & $0.101 * * *$ & $0.049 *$ & $0.093^{* * *}$ & $0.023^{* *}$ & $0.037 * * *$ & -0.023 & -0.014 & 0.032 & 0.035 & $4.160^{* * *}$ & $4.899 * * *$ \\
\hline & -0.016 & -0.019 & -0.027 & -0.029 & -0.011 & -0.013 & -0.020 & -0.021 & -0.020 & -0.022 & -1.614 & -1.688 \\
\hline \multirow[t]{2}{*}{ 3.parent_ed } & $0.0861 * * *$ & $0.125^{* * *}$ & $0.137 * * *$ & $0.186^{* * *}$ & $0.034 * * *$ & $0.049 * * *$ & $0.036^{*}$ & $0.046^{* *}$ & $0.086^{* * *}$ & $0.088^{* * *}$ & $7.769 * * *$ & $8.567 * * *$ \\
\hline & -0.016 & -0.019 & -0.026 & -0.028 & -0.011 & -0.013 & -0.020 & -0.021 & -0.020 & -0.022 & -1.590 & -1.673 \\
\hline hs_gpa & $0.167 * * *$ & $0.193^{* * *}$ & $0.960 * * *$ & $1.012^{* * *}$ & $0.066^{* * *}$ & $0.075^{* * *}$ & $0.407 * * *$ & $0.415^{* * *}$ & $0.408^{* * *}$ & $0.410^{* * *}$ & $37.46^{* * *}$ & $38.12^{* * *}$ \\
\hline
\end{tabular}

Ensuring College Readiness

[Type text] 


\begin{tabular}{|c|c|c|c|c|c|c|c|c|c|c|c|c|}
\hline & -0.005 & -0.007 & -0.016 & -0.020 & -0.003 & -0.005 & -0.010 & -0.013 & -0.012 & -0.015 & -0.600 & -0.753 \\
\hline Observations & 37,162 & 37,162 & 17,212 & 17,212 & 37,162 & 37,162 & 24,968 & 24,968 & 17419 & 17419 & 37162 & 37162 \\
\hline R-squared & & & 0.363 & 0.363 & & & & & & & 0.382 & 0.382 \\
\hline
\end{tabular}

Standard errors in parentheses *** $\mathrm{p}<0.01,{ }^{* *} \mathrm{p}<0.05,{ }^{*} \mathrm{p}<0.1$

NOTE: All predictors for binary outcomes at mean values 
Appendix 2: Wide Band Regression Outputs

\begin{tabular}{|c|c|c|c|c|c|c|c|c|c|c|c|c|}
\hline & $\begin{array}{c}(1) \\
\text { Fall-to- } \\
\text { Fall } \\
\text { Retention }\end{array}$ & $\begin{array}{c}(2) \\
\text { Fall-to- } \\
\text { Fall } \\
\text { Retention }\end{array}$ & $\begin{array}{c}\text { (3) } \\
\text { Cumulative } \\
\text { GPA }\end{array}$ & $\begin{array}{c}\text { (4) } \\
\text { Cumulative } \\
\text { GPA }\end{array}$ & $\begin{array}{c}(5) \\
\text { Fall-to- } \\
\text { Spring } \\
\text { Retention }\end{array}$ & $\begin{array}{c}(6) \\
\text { Fall-to- } \\
\text { Spring } \\
\text { Retention }\end{array}$ & $\begin{array}{c}\text { (7) } \\
\text { Gradate in } \\
\text { 4 Years }\end{array}$ & $\begin{array}{c}\text { Gradate in } \\
4 \text { Years }\end{array}$ & $\begin{array}{l}\text { Gradate in } \\
6 \text { Years }\end{array}$ & $\begin{array}{c}\text { Gradate in } \\
6 \text { Years }\end{array}$ & $\begin{array}{l}\text { Credits in } \\
4 \text { Years }\end{array}$ & $\begin{array}{c}\text { Credits in } \\
4 \text { Years }\end{array}$ \\
\hline VARIABLES & ITT & IV & ITT & IV & ITT & IV & ITT & IV & ITT & IV & ITT & IV \\
\hline \multirow[t]{2}{*}{ math_remedial } & -0.020 & -0.008 & -0.008 & 0.033 & $-0.038 * * *$ & -0.025 & $-0.048 * *$ & $-0.058^{*}$ & -0.023 & -0.014 & -2.541 & -0.950 \\
\hline & -0.019 & -0.031 & -0.044 & -0.068 & -0.014 & -0.021 & -0.022 & -0.034 & -0.032 & -0.048 & -1.851 & -3.091 \\
\hline \multirow[t]{2}{*}{ act_math_center } & -0.004 & -0.001 & 0.008 & 0.019 & -0.015 & -0.011 & -0.009 & -0.012 & -0.004 & -0.001 & -0.550 & -0.135 \\
\hline & -0.013 & -0.014 & -0.029 & -0.032 & -0.009 & -0.010 & -0.014 & -0.016 & -0.021 & -0.023 & -1.238 & -1.392 \\
\hline \multirow[t]{2}{*}{ act_math_treat_interact_wide } & -0.013 & -0.011 & 0.045 & 0.051 & -0.006 & -0.004 & -0.002 & -0.003 & 0.011 & 0.012 & 0.006 & 0.272 \\
\hline & -0.023 & -0.024 & -0.054 & -0.055 & -0.016 & -0.017 & -0.026 & -0.027 & -0.038 & -0.038 & -2.311 & -2.346 \\
\hline \multirow[t]{2}{*}{ af_american } & $0.066^{* * *}$ & $0.066^{* * *}$ & -0.016 & -0.018 & $0.057 * * *$ & $0.057 * * *$ & -0.034 & -0.034 & 0.005 & 0.004 & $7.428^{* * *}$ & $7.396^{* * *}$ \\
\hline & -0.020 & -0.020 & -0.044 & -0.044 & -0.015 & -0.015 & -0.024 & -0.024 & -0.034 & -0.034 & -1.956 & -1.956 \\
\hline \multirow[t]{2}{*}{ hispanic_other } & 0.023 & 0.024 & 0.045 & 0.046 & 0.008 & 0.008 & 0.013 & 0.012 & 0.011 & 0.012 & $4.957^{* *}$ & $4.991^{* *}$ \\
\hline & -0.025 & -0.025 & -0.069 & -0.069 & -0.017 & -0.017 & -0.031 & -0.031 & -0.047 & -0.047 & -2.440 & -2.441 \\
\hline \multirow[t]{2}{*}{ asian } & 0.041 & 0.041 & -0.133 & -0.133 & 0.012 & 0.013 & -0.087 & -0.085 & -0.073 & -0.072 & -4.547 & -4.520 \\
\hline & -0.044 & -0.044 & -0.094 & -0.094 & -0.030 & -0.030 & -0.054 & -0.054 & -0.069 & -0.069 & -4.346 & -4.356 \\
\hline \multirow[t]{2}{*}{ other_race } & $-0.044 *$ & $-0.044 *$ & -0.087 & -0.088 & 0.011 & 0.011 & -0.042 & -0.042 & -0.054 & -0.054 & -3.901 & -3.915 \\
\hline & -0.025 & -0.025 & -0.065 & -0.065 & -0.018 & -0.018 & -0.030 & -0.030 & -0.044 & -0.044 & -2.467 & -2.468 \\
\hline \multirow[t]{2}{*}{ gender_recode } & 0.002 & 0.002 & $0.185^{* * *}$ & $0.185^{* * *}$ & -0.007 & -0.007 & $0.0650^{* * *}$ & $0.065^{* * *}$ & 0.031 & 0.030 & $2.798^{* *}$ & $2.757^{* *}$ \\
\hline & -0.012 & -0.012 & -0.029 & -0.029 & -0.008 & -0.008 & -0.014 & -0.014 & -0.020 & -0.020 & -1.203 & -1.206 \\
\hline \multirow[t]{2}{*}{ pell_grant_rec } & 0.028 & 0.027 & 0.006 & 0.006 & $0.0380 *$ & $0.0379 *$ & $-0.072^{* * *}$ & $-0.072^{* * *}$ & $-0.076^{* *}$ & $-0.076^{* *}$ & 0.248 & 0.253 \\
\hline & -0.026 & -0.026 & -0.058 & -0.058 & -0.020 & -0.020 & -0.027 & -0.027 & -0.038 & -0.038 & -2.646 & -2.650 \\
\hline \multirow[t]{2}{*}{ 1.efc_recode } & $-0.092 * * *$ & $-0.092^{* * *}$ & $-0.129 *$ & $-0.129 *$ & $-0.054 *$ & $-0.054 * *$ & 0.003 & 0.004 & 0.024 & 0.024 & $-7.579 * *$ & $-7.631 * *$ \\
\hline & -0.032 & -0.032 & -0.071 & -0.071 & -0.028 & -0.028 & -0.034 & -0.034 & -0.047 & -0.047 & -3.167 & -3.171 \\
\hline \multirow[t]{2}{*}{ 2.efc_recode } & $-0.053^{* * *}$ & $-0.053^{* * *}$ & $-0.084 *$ & $-0.085^{*}$ & 0.001 & 0.001 & $-0.0354^{*}$ & $-0.035^{*}$ & $-0.078^{* *}$ & $-0.077 * *$ & $-5.310^{* * *}$ & $-5.335^{* * *}$ \\
\hline & -0.019 & -0.019 & -0.046 & -0.046 & -0.013 & -0.013 & -0.020 & -0.020 & -0.031 & -0.031 & -1.925 & -1.927 \\
\hline \multirow[t]{2}{*}{ 3.efc_recode } & -0.011 & -0.012 & -0.041 & -0.041 & 0.000 & 0.000 & -0.019 & -0.018 & -0.003 & -0.002 & -2.638 & -2.633 \\
\hline & -0.018 & -0.018 & -0.044 & -0.044 & -0.012 & -0.012 & -0.020 & -0.020 & -0.031 & -0.031 & -1.857 & -1.857 \\
\hline \multirow[t]{2}{*}{ 4.efc_recode } & -0.010 & -0.009 & -0.031 & -0.031 & 0.014 & 0.014 & 0.032 & 0.033 & 0.008 & 0.008 & 0.329 & 0.341 \\
\hline & -0.019 & -0.019 & -0.044 & -0.044 & -0.012 & -0.012 & -0.022 & -0.022 & -0.032 & -0.032 & -1.857 & -1.856 \\
\hline \multirow[t]{2}{*}{ 1.parent_ed } & 0.043 & 0.041 & -0.029 & -0.028 & 0.000 & 0.000 & -0.049 & -0.047 & -0.052 & -0.048 & -3.390 & -3.377 \\
\hline & -0.042 & -0.042 & -0.067 & -0.067 & -0.027 & -0.027 & -0.037 & -0.036 & -0.044 & -0.044 & -3.849 & -3.852 \\
\hline \multirow[t]{2}{*}{ 2.parent_ed } & $0.100^{* *}$ & $0.099 * *$ & $0.111^{*}$ & $0.112^{*}$ & 0.029 & 0.029 & -0.013 & -0.011 & 0.041 & 0.045 & 4.661 & 4.696 \\
\hline & -0.041 & -0.040 & -0.063 & -0.063 & -0.025 & -0.025 & -0.036 & -0.036 & -0.042 & -0.042 & -3.748 & -3.752 \\
\hline \multirow[t]{2}{*}{ 3.parent_ed } & $0.123^{* * *}$ & $0.121^{* * *}$ & $0.167^{* * *}$ & $0.168^{* * *}$ & 0.040 & 0.041 & 0.022 & 0.025 & $0.076^{*}$ & $0.080^{*}$ & $7.364^{* *}$ & $7.419 * *$ \\
\hline & -0.040 & -0.040 & -0.062 & -0.062 & -0.025 & -0.025 & -0.036 & -0.036 & -0.042 & -0.042 & -3.702 & -3.707 \\
\hline Ensuring College Readiness & & & & & pe text] & & & & & & & 47 \\
\hline
\end{tabular}




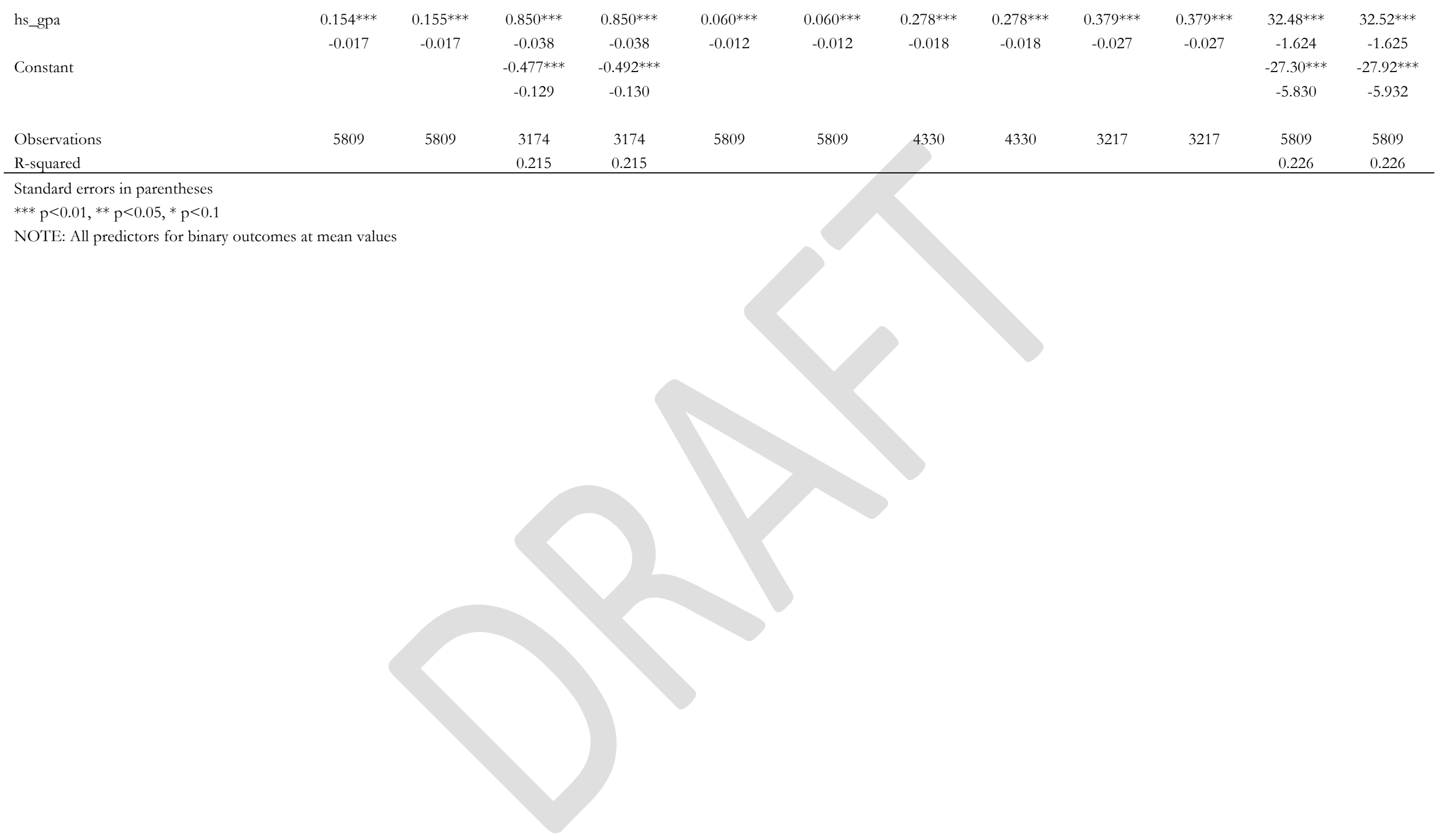




\section{Impact of English Remediation}

\begin{tabular}{|c|c|c|c|c|c|c|c|c|c|c|c|c|}
\hline VARIABLES & $\begin{array}{c}(1) \\
\text { Fall-to- } \\
\text { Fall } \\
\text { Retention } \\
\text { ITT }\end{array}$ & $\begin{array}{c}(2) \\
\text { Fall-to- } \\
\text { Fall } \\
\text { Retention } \\
\text { IV }\end{array}$ & $\begin{array}{c}\text { (3) } \\
\text { Cumulative } \\
\text { GPA } \\
\text { ITT }\end{array}$ & $\begin{array}{c}\text { Cumulative } \\
\text { GPA } \\
\text { IV }\end{array}$ & $\begin{array}{c}(5) \\
\text { Semester } \\
2 \\
\text { Retention } \\
\text { ITT }\end{array}$ & $\begin{array}{c}(6) \\
\text { Semester } \\
2 \\
\text { Retention } \\
\text { IV }\end{array}$ & $\begin{array}{c}\text { Graduate } \\
\text { in } 4 \text { Years } \\
\text { ITT }\end{array}$ & $\begin{array}{c}\text { Graduate } \\
\text { in } 4 \text { Years } \\
\text { IV }\end{array}$ & $\begin{array}{c}\text { Graduate } \\
\text { in } 6 \text { Years } \\
\text { ITT }\end{array}$ & $\begin{array}{c}(10) \\
\text { Graduate } \\
\text { in } 6 \text { Years } \\
\text { IV }\end{array}$ & $\begin{array}{c}(11) \\
\text { Credits } \\
\text { Earned in } 4 \\
\text { Years } \\
\text { ITT }\end{array}$ & $\begin{array}{c}(12) \\
\text { Credits } \\
\text { Earned in } 4 \\
\text { Years } \\
\text { IV }\end{array}$ \\
\hline \multirow[t]{2}{*}{ engl_remedial } & -0.018 & -0.004 & -0.032 & -0.031 & -0.006 & -0.014 & $-0.073 * *$ & -0.053 & -0.029 & -0.028 & $-4.863 *$ & -4.423 \\
\hline & -0.027 & -0.044 & -0.066 & -0.102 & -0.019 & -0.030 & -0.031 & -0.049 & -0.047 & -0.070 & -2.543 & -4.272 \\
\hline \multirow[t]{2}{*}{ act_eng_center_wide } & -0.015 & -0.012 & -0.011 & -0.011 & -0.002 & -0.003 & 0.015 & 0.019 & 0.025 & 0.026 & 0.115 & 0.225 \\
\hline & -0.015 & -0.016 & -0.036 & -0.038 & -0.011 & -0.011 & -0.016 & -0.017 & -0.025 & -0.027 & -1.460 & -1.563 \\
\hline \multirow[t]{2}{*}{ act_eng_treat_interact_wide } & 0.017 & 0.020 & -0.024 & -0.023 & 0.000 & -0.002 & $-0.065^{*}$ & $-0.061 *$ & -0.049 & -0.048 & -2.730 & -2.723 \\
\hline & -0.033 & -0.034 & -0.075 & -0.079 & -0.023 & -0.024 & -0.035 & -0.036 & -0.054 & -0.056 & -3.074 & -3.256 \\
\hline \multirow[t]{2}{*}{ af_american } & $0.099 * * *$ & $0.099 * * *$ & 0.032 & 0.033 & $0.065^{* * *}$ & $0.066^{* * *}$ & -0.011 & -0.011 & 0.016 & 0.016 & $10.45^{* * *}$ & $10.50^{* * *}$ \\
\hline & -0.026 & -0.026 & -0.053 & -0.053 & -0.019 & -0.019 & -0.029 & -0.029 & -0.042 & -0.042 & -2.373 & -2.375 \\
\hline \multirow[t]{2}{*}{ hispanic_other } & 0.001 & 0.001 & 0.047 & 0.049 & 0.015 & 0.015 & -0.049 & -0.049 & -0.021 & -0.020 & 1.248 & 1.256 \\
\hline & -0.029 & -0.029 & -0.095 & -0.095 & -0.020 & -0.020 & -0.036 & -0.036 & -0.058 & -0.058 & -2.723 & -2.716 \\
\hline \multirow[t]{2}{*}{ asian } & $0.078^{*}$ & $0.077^{*}$ & -0.045 & -0.044 & $0.061 * *$ & $0.061^{* *}$ & -0.059 & -0.058 & -0.010 & -0.009 & 2.965 & 2.987 \\
\hline & -0.040 & -0.040 & -0.096 & -0.096 & -0.030 & -0.030 & -0.041 & -0.041 & -0.063 & -0.063 & -3.801 & -3.809 \\
\hline \multirow[t]{2}{*}{ other_race } & $-0.0529 *$ & $-0.0529 *$ & 0.047 & 0.048 & -0.005 & -0.005 & $-0.0672 *$ & $-0.0697 *$ & -0.034 & -0.034 & 0.301 & 0.296 \\
\hline & -0.031 & -0.031 & -0.092 & -0.092 & -0.022 & -0.022 & -0.038 & -0.039 & -0.059 & -0.059 & -3.008 & -3.007 \\
\hline \multirow[t]{2}{*}{ gender_recode } & -0.008 & -0.008 & $0.143^{* * *}$ & $0.143^{* * *}$ & -0.008 & -0.008 & $0.035^{* *}$ & $0.035^{* *}$ & -0.011 & -0.010 & 0.846 & 0.844 \\
\hline & -0.015 & -0.015 & -0.034 & -0.034 & -0.010 & -0.010 & -0.015 & -0.015 & -0.024 & -0.024 & -1.395 & -1.395 \\
\hline \multirow[t]{2}{*}{ pell_grant_rec } & 0.043 & 0.042 & -0.009 & -0.010 & 0.029 & 0.029 & -0.048 & -0.049 & -0.063 & -0.063 & -1.628 & -1.694 \\
\hline & -0.032 & -0.032 & -0.086 & -0.086 & -0.025 & -0.025 & -0.038 & -0.038 & -0.051 & -0.051 & -3.312 & -3.315 \\
\hline \multirow[t]{2}{*}{ 1.efc_recode } & $-0.140^{* * *}$ & $-0.140^{* * *}$ & $-0.249 * *$ & $-0.249 * *$ & -0.051 & -0.051 & $-0.0751^{*}$ & $-0.0760^{*}$ & -0.032 & -0.033 & $-9.484 * *$ & $-9.446 * *$ \\
\hline & -0.040 & -0.040 & -0.099 & -0.099 & -0.033 & -0.033 & -0.040 & -0.040 & -0.060 & -0.060 & -3.845 & -3.848 \\
\hline \multirow[t]{2}{*}{ 2.efc_recode } & $-0.055^{* *}$ & $-0.055^{* *}$ & $-0.219 * * *$ & $-0.219 * * *$ & -0.007 & -0.007 & $-0.104 * * *$ & $-0.105^{* * *}$ & $-0.149 * * *$ & $-0.149 * * *$ & $-11.08 * * *$ & $-11.09 * * *$ \\
\hline & -0.024 & -0.024 & -0.059 & -0.059 & -0.016 & -0.016 & -0.023 & -0.023 & -0.039 & -0.039 & -2.347 & -2.348 \\
\hline \multirow[t]{2}{*}{ 3.efc_recode } & -0.034 & -0.035 & -0.075 & -0.075 & 0.005 & 0.005 & -0.029 & -0.031 & $-0.065^{*}$ & $-0.065^{*}$ & $-4.653 * *$ & $-4.678^{* *}$ \\
\hline & -0.023 & -0.023 & -0.054 & -0.054 & -0.015 & -0.015 & -0.024 & -0.024 & -0.038 & -0.038 & -2.265 & -2.266 \\
\hline \multirow[t]{2}{*}{ 4.efc_recode } & -0.002 & -0.002 & -0.017 & -0.017 & 0.016 & 0.016 & -0.004 & -0.006 & -0.010 & -0.010 & -2.119 & -2.153 \\
\hline & -0.023 & -0.023 & -0.055 & -0.055 & -0.015 & -0.015 & -0.026 & -0.026 & -0.040 & -0.040 & -2.298 & -2.297 \\
\hline \multirow[t]{2}{*}{ 1.parent_ed } & 0.084 & 0.078 & -0.014 & -0.014 & 0.016 & 0.013 & $-0.104 * *$ & $-0.118^{* *}$ & -0.037 & -0.037 & -2.514 & -2.606 \\
\hline & -0.051 & -0.051 & -0.096 & -0.096 & -0.037 & -0.036 & -0.052 & -0.053 & -0.059 & -0.059 & -5.025 & -5.025 \\
\hline \multirow[t]{2}{*}{ 2.parent_ed } & $0.116^{* *}$ & $0.110^{* *}$ & 0.032 & 0.031 & 0.044 & 0.041 & $-0.0902^{*}$ & $-0.103^{*}$ & 0.029 & 0.029 & 3.167 & 3.122 \\
\hline & -0.050 & -0.049 & -0.092 & -0.092 & -0.036 & -0.035 & -0.051 & -0.053 & -0.057 & -0.057 & -4.951 & -4.951 \\
\hline \multirow[t]{2}{*}{ 3.parent_ed } & $0.151^{* * *}$ & $0.146^{* * *}$ & $0.156^{*}$ & $0.155^{*}$ & $0.080^{* *}$ & $0.077^{* *}$ & -0.044 & -0.057 & $0.103 *$ & $0.102 *$ & 8.086 & 8.022 \\
\hline & -0.050 & -0.049 & -0.091 & -0.091 & -0.035 & -0.034 & -0.053 & -0.054 & -0.058 & -0.058 & -4.939 & -4.941 \\
\hline hs_gpa & $0.156^{* * *}$ & $0.156^{* * *}$ & $0.758^{* * *}$ & $0.758^{* * *}$ & $0.042^{* * *}$ & $0.041 * * *$ & $0.269 * * *$ & $0.270^{* * *}$ & $0.378^{* * *}$ & $0.378^{* * *}$ & $30.29 * * *$ & $30.37 * * *$ \\
\hline
\end{tabular}




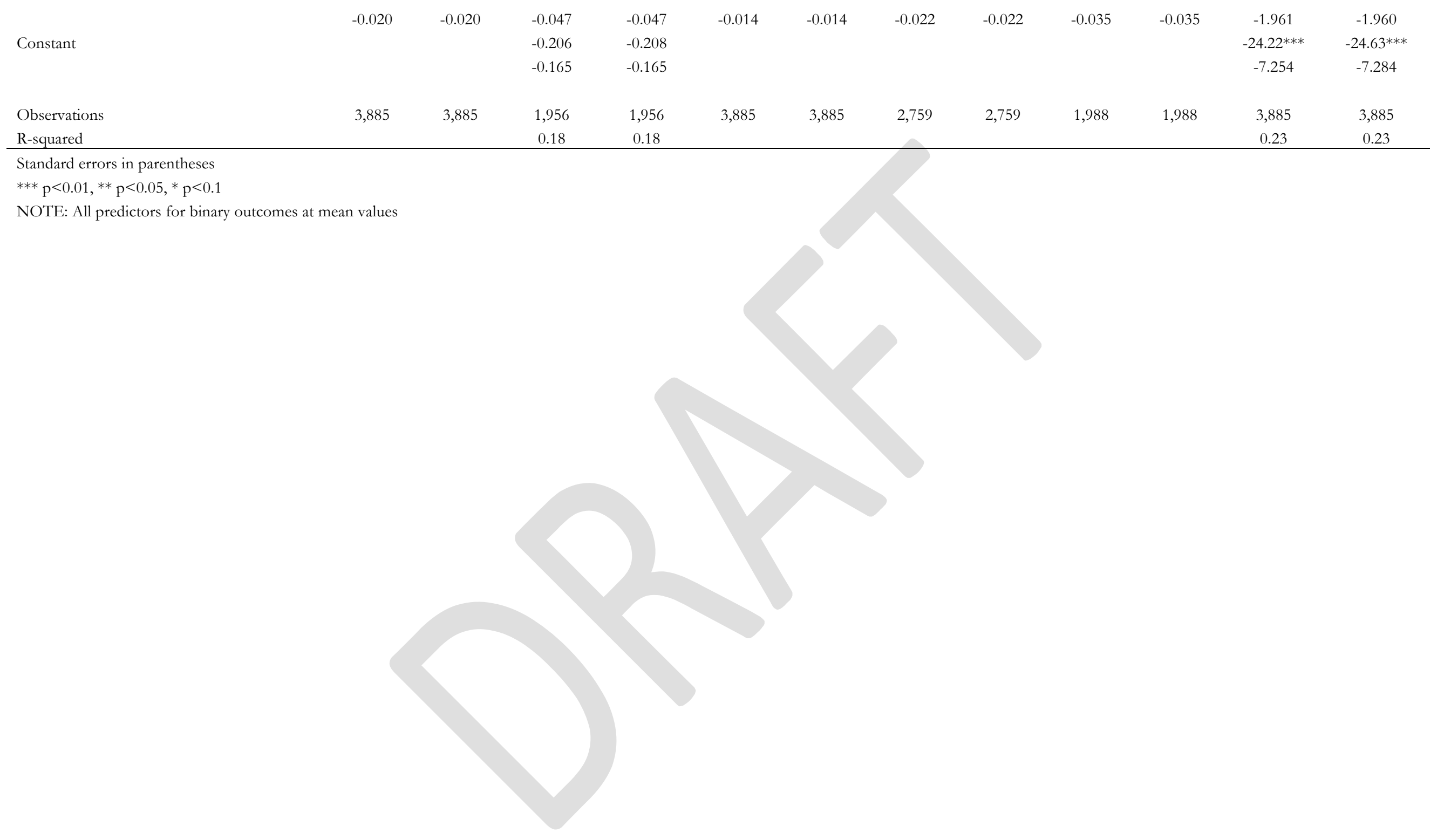




\section{Impact of Math Remediation}

Appendix 3: Narrow Band Regression Outputs

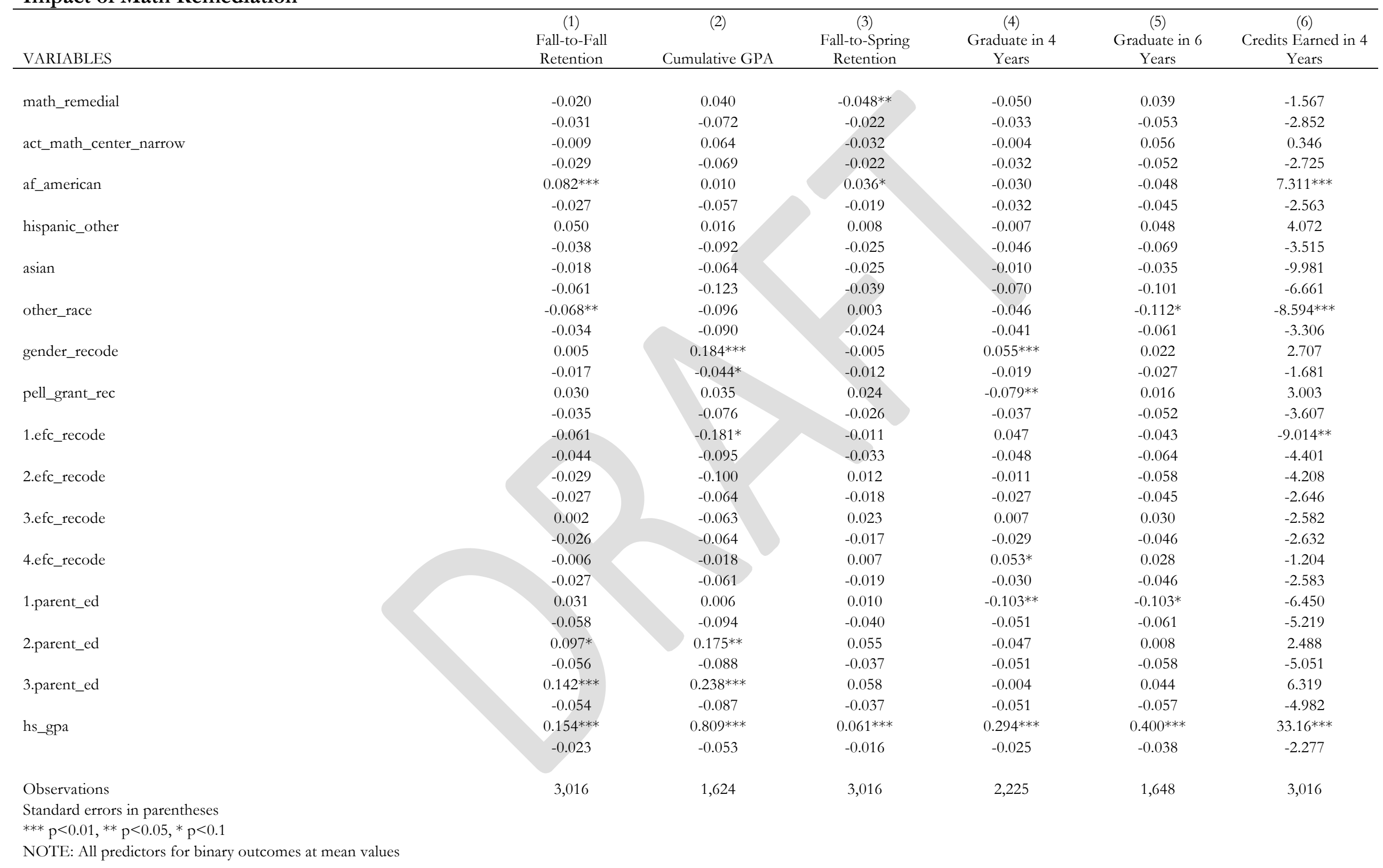




\section{Impact of English Remediation}

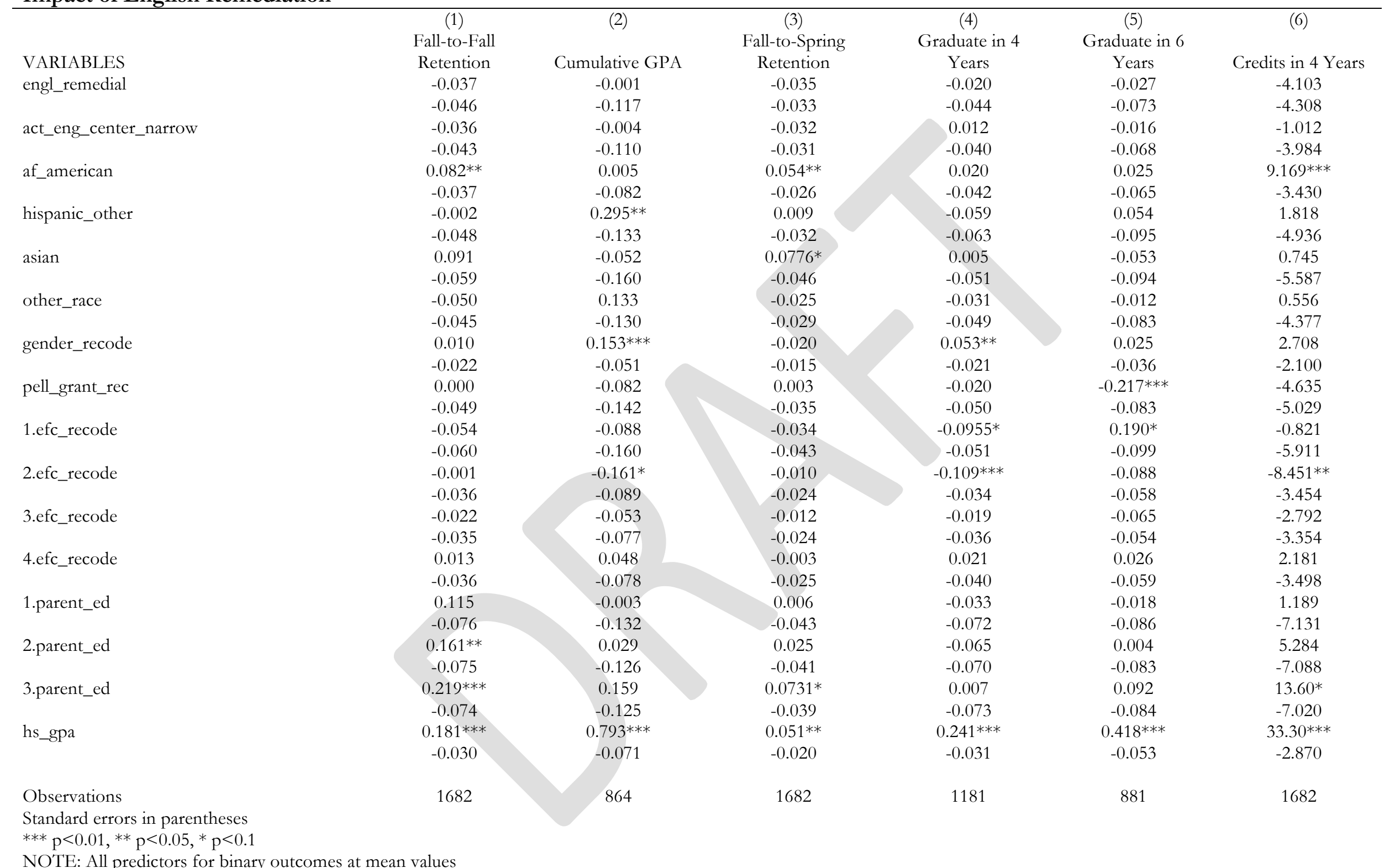

